\title{
乳霜の生歯と出生時の体重及び 体位の発亩量との関係
}

\author{
九州歯科大学口腔衛生学教室（指導：荷宫文夫教授） \\ 荷宮文夫・福成米 \\ 和田康孝 -末原靖弘
}

（本論交の要旨は昭和41年10月12日口腔衛生学会に扔いて発表した）

\section{まえがき}

乳雪の生畨についての統計的研究は、かなり多く報 告されているが、永久䨑に比べて少ない。荷宫1)は乳 雨の生曾期について、南満洲に扣いて出生した新生児 を材料として報告している。今井2) は迅速で旺盛な発 育を有する母胎内期間に扣いて、その発育に必要な栄 養の欠乏、または外的影響は、当然乳雪生雨を遅延せ しめるであろうととは考えられる。第二次大戦後化打 ける日本人の生活は、非常に困難であつた。その中に 育つた乳呪の体位が低下したととも事実である。昭和 27年の本成績は、乳迷の生茵期が戦前に㷌りつつある と発表した。丹羽3) は昭和25年より同28年の間におけ る乳米の萌出状況について、分娩時の体重の増加に従 い、平均生菌数は増加する傾向が大であるという。 丹羽4) は京橋地区の乳畨の生菡状況について、平均生 匊数の年度別、出生月別の関係仙明らかでなく、分婏

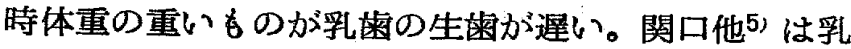
前雪の出䒨相について、笹子他6,7) は生下時の体重の 大きいちのが乳雨生橉数は少なく、出生順位第 1 子で 満期産のもので、生後 6ケ月まで母乳栄養で、母親の 教養中等以下で家族数 3 名、月額18000 20000円（昭 33年）の仹給生活者を材料とし、Kaup 指数の上のも のは乳雪生数が少ないと述へている。丹羽浮柬 の発育に及ぼす遺伝的、先天的及び後天的な諸因子と の関保について研究し、生下時上りも身長、体重の増 加により乳雨生菌数の增加が大であるという。藤田9 は乳菌萌出に関する統計学的研究を行い、風間他 ${ }^{10}$ は 東京都に抽ける9ケ月児の畨の萌出について、乳蒾の
出歯数は春に少なく、秋に多い。母親の体位と乳雨生 歯数との関係は著しくなく、母親が姙娠時に栄養郕を 飲用したものとしないものの子の差は著しくない。家 庭の採光及び通風の良否と乳霜生歯数との関係ははと

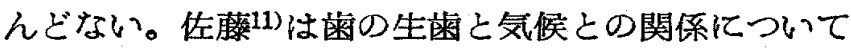

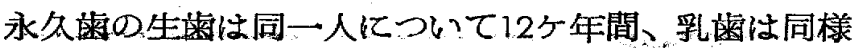
3 年6 ケ月にわたり、連続観察し、雪の生雪と気候と の間には密接な関係があり、温暖期の夏秋は寒冷期の 冬春よりす生䨑率が大であると発表した。丹羽他 ${ }^{12}$ は 乳雪の出生順位別観察について、第 1 子は第 2 子より

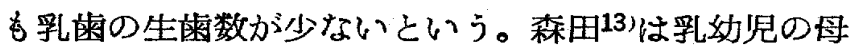
乳、人工栄養と乳雪生霜期との関係は明加でなく、出 生順位と乳雨の生歯との関係はない。母のつわりの あつたものがなかつたものよりす乳雪の生菌数が多 い。父母の年令と子の乳米現有数は、父または母の30 代の子がもつとも多く、ついで40代、20代の順に少な い。父母の最終校の差と乳荬現有数との関係はなかつ たと報告している。村下他 ${ }^{14)}$ は生下時の多いものはど 乳迷の生因は早く、混合栄養がすつとも乳曾の生雬が 早く、母乳、人工栄養の順であり、身長、体重及び胸 囲の多いるのはど乳雨の生雨が早いという。

乳霜の発育は母胎内に和いて灰化、雪冠部の形成小 どが行われるので、乳雪の生曾と出生時の体重、母親 の健康、年令などとの関係が考えられる。

私どもはてのような観点から、乳雪の生雨と出生時 の体重、生後の身長、体重の胸囲及び頭囲などの発育 量、母の年令及び両親の体重などとの関係について、 研究を行い、これらの成績の概要を報告する。 


\section{材}

料

調査した材料は、昭和40年 5 月20日より23日るで、 北九州市で行われた、西日本新聞社主催による、西日 本赤ん坊大会北九州地区審查会に出場したものであ る。対象情 10 上うに、生後50日から 450 日进での 男子507名、女子は348名、合計 855 名である。

表 1 男女別乳菊の生歯者と無生歯者 の生後日数群别人員

\begin{tabular}{|c|c|c|c|c|c|c|}
\hline \multirow{2}{*}{ 生後日数 } & \multicolumn{3}{|c|}{ 男 } & \multicolumn{3}{|c|}{ 女 } \\
\hline & 生匊者 & $\begin{array}{l}\text { 末生 } \\
\text { 者者 }\end{array}$ & 計 & 生菌者 & 条生 & 計 \\
\hline $0 \sim 49$ & & & & & & \\
\hline $50 \sim 99$ & & 16 & 16 & & 12 & 12 \\
\hline $100 \sim 149$ & & 54 & 54 & 1 & 36 & 37 \\
\hline $150 \sim 199$ & 21 & 75 & 96 & 11 & 46 & 57 \\
\hline $200 \sim 249$ & 58 & 59 & 117 & 39 & 52 & 91 \\
\hline $250 \sim 299$ & 96 & 21 & 117 & 59 & 21 & 80 \\
\hline $300 \sim 349$ & 69 & 2 & 71 & 48 & 1 & 49 \\
\hline $350 \sim 399$ & 31 & 1 & 32 & 18 & 1 & 19 \\
\hline $400 \sim 449$ & 4 & & 4 & 3 & & 3 \\
\hline 計 & 279 & 228 & 507 & 179 & 169 & 348 \\
\hline
\end{tabular}

調查は蒾について荷宮、全身は小倉記念病院小归 が行なつた。調查項目は住所、氏名、性別、出生順、 分婏の正常異常、出生時体重、出産場所、分婏予定日 と最終月径日、生後日数、家族歴怔父母の年令、身長、 体重、健康状熊、職業、同胞、流死産、血族関保、結 核、喘息、疫痢、自家中毒、尋麻疹、梅毒、精神病、 栄養、既往症、発育、栄養状熊、頭部、顔、口、嗰頭、 胸部などである。これらの調查項目のうち、今回は乳 畨の生菌と関係をみたのは、出生時体重、舟の年令、 父母の体重、身長及び本人の発育量などである。発育 量は昭和35年 5 月に実施された「厚生省乳幼肾身体発 育調查委員会による調查」加ら、九州大学医学部小児 科学教室作製の「小览発育標準表」を用いた。生後日 数の発育標準より大きいときは十とし、小さいときは 一とした。これを発育量とした。

\section{観測値の取扱い}

各人每に乳歯の生苗数加ら生後日数50日の階級に区 分し、各級每に分類した。

乳歯生霜率

$\mathrm{N}$ : 人 員

$\mathrm{T}:$ 乳雪の生霜した者

$\mathrm{P} \%$ : 乳雪生雪率、 $\mathrm{P}=\frac{\mathrm{T}}{\mathrm{N}} \times 100$
$\mathrm{Sp} \%$ : 同の標準㑲差、Sp $\%=\sqrt{\frac{\mathrm{pq}}{\mathrm{N}}}, \mathbf{q}=100-\mathrm{p}$ 乳霜生菡数

$\mathrm{N}$ : 人 員

$\mathrm{x}$ : 生歯数

$\mathrm{X}:$ 平均生㐘数、 $\overline{\mathrm{X}}=\frac{\Sigma \mathrm{X}}{\mathrm{N}}$

$\mathrm{S}^{2} \mathrm{x}: \mathrm{X}$ の分散、 $\mathrm{S}^{2} \mathrm{x}=\frac{\sum x^{2}}{\mathrm{~N}-1} 、 x=\mathrm{X}-\mathrm{\textrm {X }}$

身長、体重、胸团及び頭囲の発有量の平均及び分散 は、これに準ずる。

二つの平均值の差の判定

$\mathrm{N}_{1} 、 \mathrm{~N}_{2}$ : 人 員

$\overline{\mathrm{X}} 、 \mathrm{Y}$ : 平均

$S^{2} X 、 S^{2} Y: X 、 Y$ 分散

$\omega^{2}: X 、 Y$ 共同分散、

$$
\begin{aligned}
& \omega^{2}=\frac{S^{2} X\left(N_{1}-1\right)+S^{2} \mathbf{Y}\left(N_{2}-1\right)}{N_{1}+N_{2}-2} \\
& \text { to }=\frac{\bar{X}-\bar{Y}}{\omega \sqrt{\frac{1}{N_{1}}+\frac{1}{N_{2}}}}
\end{aligned}
$$

to $の$ 值が $\mathrm{t}$-表の $2=0.05 、 \mathrm{n}=\mathrm{N}_{\mathbf{1}}+\mathrm{N}_{\mathbf{2}}-2$ 亿相当 する $\mathrm{t}$ 值より大きいとき法、二つの平均值の差仙偶然 の所産でなく、二つの平均值の差に危険度 $5 \%$ 以下に 扣いて、有意義性がありとした。

二つの生菌率 $\left(\mathbf{P}_{1} \pm \mathrm{Sp}_{1} 、 \mathrm{P}_{2} \pm \mathrm{Sp}_{2}\right)$ の差

$\mathrm{d}:$ : つの生蒾率の差、 $\mathrm{d}=\mathrm{P}_{\mathbf{1}}-\mathrm{P}_{\mathbf{2}}$

$\mathrm{Sd}: \mathrm{d}$ の標準偏差、 $\mathrm{Sd}=\sqrt{\mathrm{S}^{2} \mathbf{p}_{\mathbf{1}}+\mathrm{S}^{\mathbf{2}} \mathbf{p}_{\mathbf{2}}}$

$\mathrm{d} / \mathrm{Sd}$ の值がフ.96より大きいときには、この差は偶 然の所産なく、危険度 $5.0 \%$ 以下に扔いて有意義性肪 ありとした。

群について

$\mathrm{MR}$ : 平均比、 $\mathrm{MR}=\frac{\Sigma(\mathrm{to})}{\mathrm{K}}, \mathrm{K}:$ 比較した級数

$S_{M R}: M R$ の標準偏差 $S_{M R}=\frac{1}{\sqrt{K-1}}$

MR が $O$ を中心として、 $S_{M R}=1 /|K-1| 1 / 2$ をむつて正規分布するとすれば、MR が $\mathrm{S}_{\mathrm{MM}}$ の1.96 倍上り大きいときには、偶然の所産でなく、危険度 5 \%以下に扔いて有意義性がありとした。

\section{成}

績

\section{1. 乳菌生菌率}

乳歯生菌率仙表 1 の通りで、男子が507名の中279名、 $55.0 \%$ 、女子は 348 名中 179 名、 $51.4 \%$ である。生後日 数を class unit 50日とし、各級每の乳霜生霜率は、 生後日数が๋150〜199日の男子は $21.5 \%$ 、女は19.3\%で 生後日数の増すにつれて增率し、男女とるに生後日数 
が400～449日には $100.0 \%$ となり、男女間の生霜率の 差はほとんどない。

\section{2. 生後日数と乳茵の生茵数}

男女別に生後日数群別に、乳雷平均生画数は表 $2 、$ 3 の通りである。

表 2

男：生後日数群別乳曾生曾数度数分布

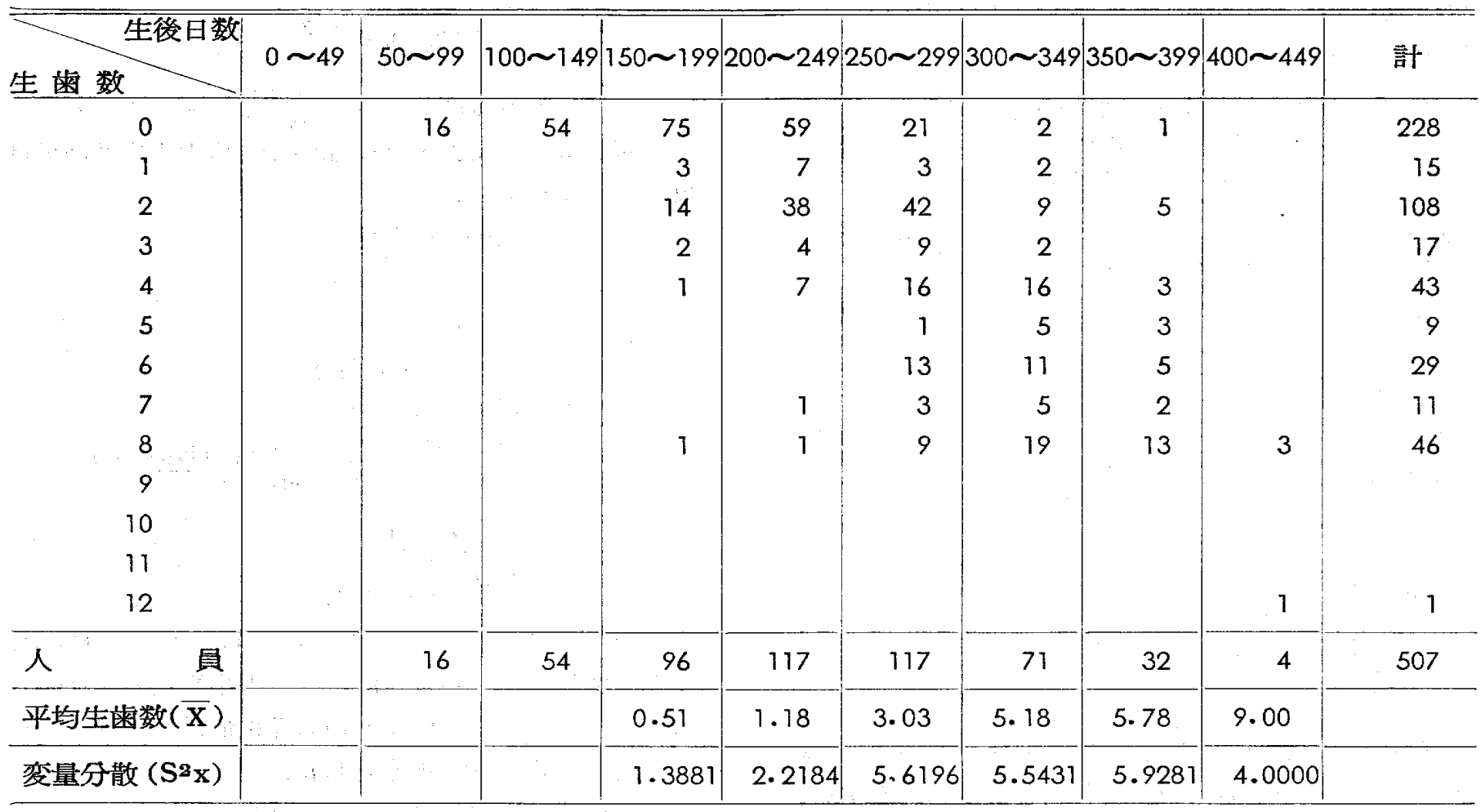

表 3

女：生後日数群別乳歯生歯数度数分在

\begin{tabular}{|c|c|c|c|c|c|c|c|c|c|c|}
\hline 生 歯 数 & $0 \sim 49$ & $50 \sim 99$ & $100 \sim 1497$ & $50 \sim 199 \mid 2$ & $200 \sim 249$ & $250 \sim 299$ & $300 \sim 349$ & $|350 \sim 399|$ & $400 \sim 449$ & 計 \\
\hline \begin{tabular}{|r|}
0 \\
1 \\
2 \\
3 \\
4 \\
5 \\
6 \\
7 \\
8 \\
9 \\
10 \\
11 \\
12 \\
\end{tabular} & $\therefore$ & . & $\begin{array}{r}36 \\
\quad 1\end{array}$ & $\begin{array}{r}46 \\
2 \\
7 \\
1 \\
1\end{array}$ & $\begin{array}{r}52 \\
8 \\
26 \\
1 \\
3 \\
1\end{array}$ & $\begin{array}{r}21 \\
34 \\
1 \\
14 \\
1 \\
5 \\
2 \\
2\end{array}$ & $\begin{array}{r}1 \\
1 \\
16 \\
2 \\
10 \\
2 \\
6 \\
4 \\
7\end{array}$ & $\begin{array}{l}1 \\
1 \\
3 \\
4 \\
\\
2 \\
1 \\
6\end{array}$ & 2 & $\begin{array}{r}169 \\
12 \\
87 \\
5 \\
32 \\
4 \\
13 \\
7 \\
17\end{array}$ \\
\hline 人 員 & & 12 & 37 & 57 & 91 & 80 & 49 & 19 & 3 & 348 \\
\hline 平均生菌数 $(\overline{\mathrm{Y}})$ & & & 0.05 & 0.40 & 0.88 & 2.40 & 4.27 & 5.37 & 9.33 & \\
\hline 変量分散 $\left(\mathrm{S}^{2}{ }_{\mathrm{Y}}\right)$ & & & 0.0919 & 0.8050 & 1.3761 & 4.2937 & 5.4272 & 9.9011 & 5.3267 & \\
\hline
\end{tabular}


生後日数150～199日亿男子は平均 0.5 本、女子は平 均 0.1 本で、男子とを生後日数を增す。生後日数が 400 499日に男子は平均 9.0 本、女子は平均 9.3 本で
ある。男女間の乳霜平均生歯数は男子が女子よりす 多い。
表 4

\begin{tabular}{|c|c|c|c|c|c|c|c|c|c|c|c|c|}
\hline \multirow{2}{*}{\multicolumn{3}{|c|}{$\begin{array}{l}\text { 生每平均数 } \\
\text { 生後日数 }\end{array}$}} & \multicolumn{3}{|c|}{ 男 } & \multicolumn{3}{|c|}{ 女 } & \multicolumn{4}{|c|}{ 男 - 女 } \\
\hline & & & $\mathrm{N}_{1}$ & $\overline{\mathbf{x}}$ & $\mathrm{S}^{2} \mathrm{x}$ & $\mathrm{N}_{2}$ & $\overline{\mathbf{Y}}$ & $\mathrm{S}^{2} \mathrm{Y}$ & $\mathrm{n}$ & d & $\omega^{2}$ & $t_{0}$ \\
\hline 100 & $\sim$ & 149 & & & & 37 & 0.05 & 0.0919 & & & & \\
\hline 150 & $\sim$ & 199 & 96 & 0.51 & 1.3881 & 57 & 0.40 & 0.8050 & 151 & 0.11 & 1.1719 & 0.609 \\
\hline 200 & $\sim$ & 249 & 117 & 1.18 & 2.2184 & 91 & 0.88 & 1.3761 & 206 & 0.30 & 1.8504 & 1.577 \\
\hline 250 & $\sim$ & 299 & 117 & 3.03 & 5.6196 & 80 & 2.40 & 4.2937 & 195 & 0.63 & 5.0824 & 1.912 \\
\hline 300 & $\sim$ & 349 & 71 & 5.18 & 5.5431 & 49 & 4.27 & 5.4272 & 118 & 0.91 & 5.4960 & 2.096 \\
\hline 350 & $\sim$ & 399 & 32 & 5.78 & 5.9281 & 19 & 5.37 & 9.9011 & 49 & 0.41 & 7.3876 & 0.520 \\
\hline 400 & $\sim$ & 449 & 4 & 9.00 & 4.0000 & 3 & 9.33 & 5.3267 & 5 & -0.33 & 4.5307 & -0.203 \\
\hline
\end{tabular}

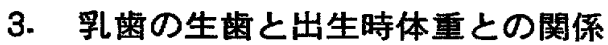

乳曾の生歯と出生時の体重との関係をみるために、
乳雨生歯者と末生歯者別に、生後日数群別の出生時の 平均体重を比べると、表 5、6の通りである。

表 5 生歯者の生後日数群別出生時平均体重の男女間の差

(kg)

\begin{tabular}{|c|c|c|c|c|c|c|c|c|c|c|c|c|}
\hline \multirow{2}{*}{\multicolumn{3}{|c|}{$\begin{array}{l}\text { 生椟平均数 } \\
\text { 生後日数 }\end{array}$}} & \multicolumn{3}{|c|}{ 男 } & \multicolumn{3}{|c|}{ 女 } & \multicolumn{4}{|c|}{ 男 一 女 } \\
\hline & & & $\mathbf{N}_{1}$ & $\overline{\mathbf{X}}$ & $S^{2} x$ & $\mathrm{~N}_{2}$ & $\overline{\mathbf{X}}$ & $S^{2} \mathrm{Y}$ & $\mathbf{n}$ & d & $\omega^{2}$ & $t_{o}$ \\
\hline 100 & $\sim$ & 149 & & & & 1 & 3.40 & 0 & & & & \\
\hline 150 & $\sim$ & 199 & 21 & 3.59 & 0.1780 & 11 & 3.48 & 0.2884 & 30 & 0.11 & 0.2148 & 0.643 \\
\hline 200 & $\sim$ & 249 & 57 & 3.36 & 0.1754 & 38 & 3.30 & 0.0886 & 93 & 0.06 & 0.1409 & 0.775 \\
\hline 250 & $\sim$ & 299 & 92 & 3.36 & 0.2763 & 57 & 3.30 & 0.1609 & 147 & 0.06 & 0.2323 & 0.741 \\
\hline 300 & $\sim$ & 349 & 69 & 3.40 & 0.2185 & 45 & 3.28 & 0.1041 & 112 & 0.12 & 0.1736 & 1.529 \\
\hline 350 & $\sim$ & 399 & 31 & 3.22 & 0.1915 & 18 & 3.09 & 0.4211 & 47 & 0.13 & 0.2745 & 0.843 \\
\hline 400 & $\sim$ & 449 & 4 & 3.20 & 0.2600 & 3 & 3.10 & 0.3600 & 5 & 0.10 & 0.3000 & 0.243 \\
\hline \multicolumn{3}{|c|}{$K=6$} & \multicolumn{10}{|c|}{$\mathrm{MR} / \mathrm{S}_{\mathrm{MR}}=1.783$} \\
\hline
\end{tabular}

表 6

未生雪者：男と女の生後日数群別出生時平均体重の差

$(\mathrm{Kg})$

\begin{tabular}{|c|c|c|c|c|c|c|c|c|c|c|c|c|}
\hline \multirow{2}{*}{\multicolumn{3}{|c|}{$\begin{array}{l}\text { 生憐平均数 } \\
\text { 生後日数 }\end{array}$}} & \multicolumn{3}{|c|}{ 男 } & \multicolumn{3}{|c|}{ 女 } & \multicolumn{4}{|c|}{ 男 - 女 } \\
\hline & & & $\mathbf{N}_{1}$ & $\overline{\mathbf{X}}$ & $S^{2} x$ & $\mathrm{~N}_{2}$ & $\overline{\mathbf{Y}}$ & $S^{2} \mathbf{Y}$ & $\mathbf{n}$ & d & $\omega^{2}$ & $t_{o}$ \\
\hline 50 & $\sim$ & 99 & 16 & 3.32 & 0.2212 & 12 & 3.28 & 0.1796 & 26 & 0.04 & 0.2036 & 0.233 \\
\hline 100 & $\sim$ & 149 & 54 & 3.35 & 0.3752 & 36 & 3.26 & 0.0995 & 88 & 0.09 & 0.2655 & 0.821 \\
\hline 150 & $\sim$ & 199 & 74 & 3.30 & 0.1567 & 46 & 3.14 & 0.1328 & 118 & 0.16 & 0.1476 & 2.240 \\
\hline 200 & $\sim$ & 249 & 58 & 3.21 & 0.2127 & 51 & 3.24 & 0.1409 & 107 & -0.03 & 0.1791 & -0.372 \\
\hline 250 & $\sim$ & 299 & 20 & 3.29 & 0.2257 & 20 & 3.02 & 0.2706 & 38 & 0.27 & 0.2482 & 1.741 \\
\hline 300 & $\sim$ & 349 & 2 & 3.05 & 0.0050 & 1 & 3.80 & 0 & 1 & -0.75 & 0.0050 & -8.679 \\
\hline 350 & $\sim$ & 399 & 1 & 3.21 & 0 & 1 & 3.90 & 0 & 0 & -0.69 & 0 & 0 \\
\hline
\end{tabular}


乳菡生䨑者の出生時平均体重は、男子分女子小りも わずかけ大である。乳霜未生霜者の出生時平均体重は 女子が男子よりもわずかに大である。
男女別に乳歯生歯者と乳雪未生蒾者の出生時平均体 重を比べると、表7、8の通りである。

表 7

男：生後日数群別生雬者と末生雨者の出生時平均体重の差

( $\left.\dot{K}_{g}\right)$

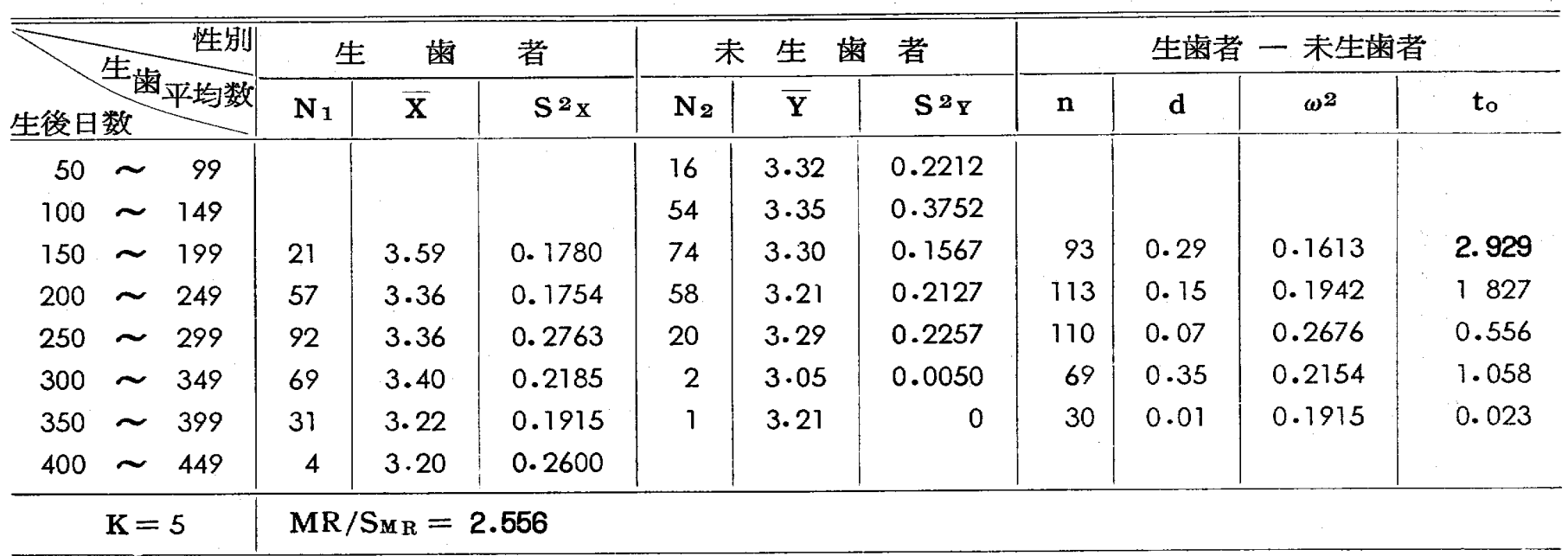

表 8

女：生後日数群別生柬者と末生霜者の出生時平均体重の差

$(\mathrm{Kg})$

\begin{tabular}{|c|c|c|c|c|c|c|c|c|c|c|c|}
\hline \multirow{2}{*}{\multicolumn{2}{|c|}{$\begin{array}{l}\text { 生菌平均数 } \\
\text { 生後日数 }\end{array}$}} & \multicolumn{2}{|c|}{ 生 } & \multirow{2}{*}{$\begin{array}{l}\text { 者 } \\
\mathbf{S}^{2} \mathbf{x} \\
\end{array}$} & \multicolumn{3}{|c|}{ 未生雪 者 } & \multicolumn{4}{|c|}{ 生雬者 一 未生雬者 } \\
\hline & & $\mathbf{N}_{1}$ & $\overline{\mathbf{X}}$ & & $\mathrm{N}_{2}$ & $\overline{\mathbf{Y}}$ & $S^{2} \mathbf{Y}$ & $\mathrm{n}$ & d & $\omega^{2}$ & $t_{o}$ \\
\hline 50 & $\sim 99$ & & & & 12 & 3.28 & 0.1796 & & & & \\
\hline 100 & $\sim 149$ & 1 & 3.40 & 0 & 36 & 3.26 & 0.0995 & 35 & 0.14 & 0.0995 & 0.443 \\
\hline 150 & $\sim 199$ & 11 & 3.48 & 0.2884 & 46 & 3.14 & 0.1328 & 55 & 0.34 & 0.1611 & 2.533 \\
\hline 200 & $\sim 249$ & 38 & 3.30 & 0.0886 & 51 & 3.24 & 0.1409 & 87 & 0.06 & 0.1187 & 0.824 \\
\hline 250 & $\sim 299$ & 57 & 3.30 & 0.1609 & 20 & 3.02 & 0.2706 & 75 & 0.28 & 0.1887 & 2.507 \\
\hline 300 & $\sim 349$ & 45 & 3.28 & 0.1041 & 1 & 3.80 & 0 & 44 & -0.52 & 0.1041 & -1.593 \\
\hline 350 & $\sim 399$ & 18 & 3.09 & 0.4211 & 1 & 3.90 & 0 & 17 & -0.81 & 0.4211 & -1.228 \\
\hline 400 & $\sim 449$ & 3 & 3.10 & 0.3600 & & & & & & & \\
\hline & $K=6$ & MR & $\mathbf{R}-$ & & & & & & & & \\
\hline
\end{tabular}

男子は乳乳雬生歯者が乳歯末生荬者よりも出生時平 均体重が大で、女子は乳霜生歯者が末生霜者よりもわ ずかに大である。

\section{4. 男と女の乳歯生数別出生時平均体重の差}

1）生後日数 200〜249日と 200〜299日及び250〜 299 日の乳雬の生曾数別平均体重の男女間の差
生後日数200〜249日、200〜299日及び250〜299日の 乳歯の生菊数別出生時の平均体重の男女間の差は、表 9、10、11の通りである。

生後日数200〜249日の女子が男子よりもわずが隹子 きく、200〜299日及び250～299日では、男女間の差は はとんどない。 
9

生後日数（200～249日）の男女間の生菊数別出生時平均体重の差

$(\mathrm{Kg})$

\begin{tabular}{|c|c|c|c|c|c|c|c|c|c|c|c|}
\hline \multirow{2}{*}{ 生 } & \multirow{2}{*}{ 雪 数 } & \multicolumn{3}{|c|}{ 男 } & \multicolumn{3}{|c|}{ 女 } & \multicolumn{4}{|c|}{ 男 一 女 } \\
\hline & & $\mathbf{N}_{\mathbf{I}}$ & $\overline{\mathbf{X}}$ & $S^{2_{X}}$ & $\mathbf{N}_{2}$ & $\overline{\mathbf{Y}}$ & $S^{2} Y$ & $\mathbf{n}$ & d & $\omega^{2}$ & $t_{0}$ \\
\hline \multicolumn{2}{|r|}{1} & 7 & 3.26 & 0.2058 & 8 & 3.38 & 0.0241 & 13 & -0.12 & 0.1080 & -0.702 \\
\hline \multicolumn{2}{|r|}{2} & 37 & 3.34 & 0.1770 & 26 & 3.36 & 0.1019 & 61 & -0.02 & 0.1462 & -0.206 \\
\hline \multicolumn{2}{|r|}{3} & 4 & 3.35 & 0.0300 & 1 & 3.70 & 0 & 3 & -0.35 & 0.0300 & -1.832 \\
\hline \multicolumn{2}{|r|}{4} & 7 & 3.39 & 0.1582 & 2 & 3.55 & 0.1250 & 7 & -0.15 & 0.1535 & -0.481 \\
\hline \multicolumn{2}{|r|}{5} & & & & 1 & 3.40 & 0 & & & & \\
\hline \multicolumn{2}{|r|}{7} & 1 & 4.40 & 0 & & & & & & & \\
\hline \multicolumn{2}{|r|}{8} & 1 & 3.40 & 0 & & & & & & & \\
\hline \multicolumn{2}{|c|}{$\mathrm{K}=4$} & \multicolumn{10}{|c|}{$\mathrm{MR} / \mathrm{S}_{\mathrm{MR}}=-1.395$} \\
\hline & \multicolumn{4}{|l|}{10} & \multicolumn{6}{|c|}{ : 男と女の生橉数別出生時平均体重の差 } & $(\mathrm{Kg})$ \\
\hline \multirow{2}{*}{\multicolumn{2}{|c|}{ 生 菌 数 }} & \multicolumn{3}{|c|}{ 男 } & \multicolumn{3}{|c|}{ 女 } & \multicolumn{4}{|c|}{ 男 一 女 } \\
\hline & & $\mathrm{N}_{1}$ & $\mathrm{x}$ & $S^{2} x$ & $\mathrm{~N}_{2}$ & $\overline{\mathbf{Y}}$ & $S^{2} \mathbf{Y}$ & $\mathbf{n}$ & d & $\omega^{2}$ & to \\
\hline & 1 & 10 & 3.21 & 0.3588 & 8 & 3.38 & 0.0241 & 16 & -0.17 & 0.2124 & -0.780 \\
\hline & 2 & 77 & 3.36 & 0.1564 & 59 & 3.24 & 0.1285 & 134 & 0.12 & 0.1443 & 1.825 \\
\hline & 3 & 13 & 3.28 & 0.1621 & 2 & 3.50 & 0.0800 & 13 & -0.22 & 0.1558 & -0.726 \\
\hline & 4 & 22 & 3.33 & 0.2296 & 15 & 3.44 & 0.1797 & 35 & -0.11 & 0.2096 & -0.715 \\
\hline & 5 & 1 & 3.61 & 0 & 2 & 3.40 & 0 & 1 & 0.21 & 0 & 0 \\
\hline & 6 & 12 & 3.42 & 0.2152 & 5 & 3.28 & 0.1995 & 15 & 0.14 & 0.2110 & 0.572 \\
\hline & 7 & 4 & 3.75 & 0.4633 & 2 & 3.50 & 0.1800 & 4 & 0.25 & 0.3925 & 0.460 \\
\hline & 8 & 10 & 3.70 & 0.0889 & 2 & 3.35 & 0.2450 & 10 & 0.35 & 0.1045 & 1.411 \\
\hline & $\mathrm{K}=8$ & $\mathbf{M R}$ & $\mathrm{MR}_{\mathrm{R}}=$ & & & & & & & & \\
\hline
\end{tabular}

表 11

生後日数（250～299日）：男と女の生菡数別出生時平均体重の差

$(\mathrm{Kg})$

\begin{tabular}{|c|c|c|c|c|c|c|c|c|c|c|c|}
\hline \multirow{2}{*}{ 生 } & \multirow{2}{*}{ 雪 } & \multicolumn{3}{|c|}{ 男 } & \multicolumn{3}{|c|}{ 女 } & \multicolumn{4}{|c|}{ 男 一 女 } \\
\hline & & $\mathbf{N}_{1}$ & $\overline{\mathbf{X}}$ & $\mathbf{s}^{2} \mathrm{x}$ & $\mathbf{N}_{2}$ & $\overline{\mathbf{Y}}$ & $S^{2} \mathbf{Y}$ & $\mathbf{n}$ & d & $\omega^{2}$ & $t_{o}$ \\
\hline & 1 & 3 & 3.37 & 0.9700 & & & & & & & \\
\hline & 2 & 40 & 3.38 & 0.1404 & 33 & 3.23 & 0.1562 & 71 & 0.15 & 01475 & 1.678 \\
\hline & 3 & 9 & 3.14 & 0.1742 & 1 & 3.30 & 0 & 8 & -0.16 & 0.1742 & -0.358 \\
\hline & 4 & 15 & 3.32 & 0.2731 & 13 & 3.42 & 0.1977 & 26 & -0.10 & 0.2383 & -0.539 \\
\hline & 5 & 1 & 3.70 & 0 & 1 & 3.40 & 0 & 0 & 0.30 & 0 & 0 \\
\hline & 6 & 12 & 3.42 & 0.2152 & 5 & 328 & 0.1970 & 15 & 0.14 & 0.2103 & 0.572 \\
\hline & 7 & 3 & 3.53 & 0.4107 & 2 & 3.50 & 0.1800 & 3 & 0.03 & 0.3338 & 0.057 \\
\hline & 8 & 9 & 3.73 & 0.0877 & 2 & 3.35 & 0.2450 & 9 & 0.38 & 0.1052 & 1.474 \\
\hline & $K=7$ & \multicolumn{10}{|c|}{$\mathbf{M R} / \mathbf{S}_{\mathbf{M R}}=1.010$} \\
\hline
\end{tabular}

口）生後日数200〜249日と250〜299日間の出生時 の平均体重の差

男女別に生後日数200～249日と250～299日間の乳霜 生篓数別出生時の平体重を比べると、表12、13の通り
である。

男女ともに両生後日数群間に、出生時の平均体重と の差は、はとんどない。 
表 12 男: 生後日数(200〜249日)と(250～299日)間の生歯数別出生時平均体重の差

$(\mathrm{Kg})$

\begin{tabular}{|c|c|c|c|c|c|c|c|c|c|c|c|}
\hline \multirow{2}{*}{ 生 } & \multirow{2}{*}{ 歯 } & \multicolumn{3}{|c|}{ 生後日数 (200～249日) } & \multicolumn{3}{|c|}{ 生後日数 (250～299日) } & \multicolumn{4}{|c|}{$(200 \sim 249$ 日 $)-(250 \sim 299$ 日 $)$} \\
\hline & & $\mathrm{N}_{1}$ & $\overline{\mathbf{X}}$ & $\mathrm{S}^{2} \mathrm{x}$ & $\mathrm{N}_{2}$ & $\overline{\mathbf{Y}}$ & $\mathrm{S}^{2} \mathrm{Y}$ & $\mathbf{n}$ & $\mathrm{d}$ & $\omega^{2}$ & $t_{0}$ \\
\hline & 1 & 7 & 3.26 & 0.2058 & 3 & 3.37 & 0.9700 & 8 & -0.11 & 0.3969 & -0.253 \\
\hline & 2 & 37 & 3.34 & 0.1770 & 40 & 3.38 & 0.1404 & 75 & -0.04 & 0.1580 & -0.438 \\
\hline & 3 & 4 & 3.35 & 0.0300 & 9 & 3.14 & 0.1742 & 11 & 0.21 & 0.1349 & 0.942 \\
\hline & 4 & 7 & 3.39 & 0.1582 & 15 & 3.32 & 0.2731 & 20 & 0.07 & 0.2386 & 0.313 \\
\hline & 5 & & & & 1 & 3.70 & 0 & & & & \\
\hline & 6 & & & & 12 & 3.42 & 0.2152 & & & & \\
\hline & 7 & 1 & 4.40 & 0 & 3 & 3.53 & 0.4107 & 2 & 0.87 & 0.4107 & 1.169 \\
\hline & 8 & 1 & 3.40 & 0 & 9 & 3.73 & 0.0877 & 8 & -0.33 & 0.0877 & -1.034 \\
\hline
\end{tabular}

$\mathbf{K}=6$

$\mathrm{MR} / \mathrm{S}_{\mathrm{MR}}=0.186$

表 13 女：生後日数群の(200〜249日)と(250 299日) 間の生歯数別出生時平均体重の差

$(\mathrm{Kg})$

\begin{tabular}{|c|c|c|c|c|c|c|c|c|c|c|c|}
\hline \multirow{2}{*}{ 生 } & \multirow{2}{*}{ 歯 } & \multicolumn{3}{|c|}{ 生後日数 (200～249日) } & \multicolumn{3}{|c|}{ 生後日数 (250～299日) } & \multicolumn{4}{|c|}{$(200 \sim 249$ 日 $)-(250 \sim 299$ 日 $)$} \\
\hline & & $\mathrm{N}_{1}$ & $\overline{\mathbf{X}}$ & $S^{2} x$ & $\mathrm{~N}_{2}$ & $\overline{\mathbf{Y}}$ & $S^{2} \mathbf{Y}$ & $\mathbf{n}$ & $\mathrm{d}$ & $\omega^{2}$ & $t_{o}$ \\
\hline & 1 & 8 & 3.38 & 0.024 & & & & & & & \\
\hline & 2 & 26 & 3.36 & 0.1019 & 33 & 3.23 & 0.1562 & 57 & 0.13 & 0.1324 & 1.376 \\
\hline & 3 & 1 & 3.70 & 0 & 1 & 3.30 & 0 & 0 & 0.40 & 0 & 0 \\
\hline & 4 & 2 & 3.55 & 0.1250 & 13 & 3.42 & 0.1977 & 13 & 0.13 & 0.1921 & 0.390 \\
\hline & 5 & 1 & 3.40 & 0 & 1 & 3.40 & 0 & 0 & 0 & 0 & 0 \\
\hline & 6 & & & & 5 & 3.28 & 0.1970 & & & & \\
\hline & 7 & & & & 2 & 3.50 & 0.1800 & & & & \\
\hline & 8 & & & & 2 & 3.35 & 0.2450 & & & & \\
\hline & $K=4$ & MI & $\mathbf{R}=$ & & & & & & & & \\
\hline
\end{tabular}

\section{5. 乳雷の生歯と身長平均発育量}

i）男子と女子の差

乳菌の生崡者、未生菌者䎲つて、男子と女子の生

生䨑者：男と女の生後日数群別身長平均発育量の差

(cm)

\begin{tabular}{|c|c|c|c|c|c|c|c|c|c|c|c|c|}
\hline \multirow{2}{*}{\multicolumn{3}{|c|}{$\begin{array}{l}\text { 生雨平均数 } \\
\text { 生後日数 }\end{array}$}} & \multicolumn{3}{|c|}{ 男 } & \multicolumn{3}{|c|}{ 女 } & \multicolumn{4}{|c|}{ 男 - 女 } \\
\hline & & & $\mathrm{N}_{1}$ & $\bar{x}$ & $S^{2} x$ & $\mathrm{~N}_{2}$ & $\overline{\mathbf{Y}}$ & $S^{2} \mathbf{Y}$ & $\mathbf{n}$ & d & $\omega^{2}$ & $t_{0}$ \\
\hline 100 & $\sim$ & 149 & & & & 1 & 2.40 & 0 & & & & \\
\hline 150 & $\sim$ & 199 & 21 & 2.67 & 4.3656 & 11 & 2.05 & 2.6473 & 30 & 0.62 & 3.7928 & 0.855 \\
\hline 210 & $\sim$ & 249 & 58 & $2 \cdot 20$ & 4.0130 & 39 & 1.57 & 3.9618 & 95 & 0.63 & 3.9925 & 1.521 \\
\hline 250 & $\sim$ & 299 & 96 & 2.39 & 4.8434 & 59 & 2.03 & 5.2272 & 153 & 0.36 & 4.9889 & 0.975 \\
\hline 300 & $\sim$ & 349 & 69 & 2.63 & 5.8295 & 47 & 2.58 & 4.8798 & 114 & 0.05 & 5.4463 & 0.114 \\
\hline 350 & $\sim$ & 399 & 31 & 1.93 & 3.9873 & 18 & 2.52 & 10.6140 & 47 & -0.59 & 6.3842 & -0.786 \\
\hline 400 & $\sim$ & 449 & 4 & 2.65 & 8.0300 & 3 & 2.90 & 0.6351 & 5 & -0.25 & 5.0720 & -0.146 \\
\hline \multicolumn{3}{|c|}{$K=6$} & \multicolumn{10}{|c|}{$\mathrm{MR} / \mathrm{S}_{\mathrm{MR}}=0.946$} \\
\hline
\end{tabular}




\begin{tabular}{|c|c|c|c|c|c|c|c|c|c|c|c|c|}
\hline \multirow{2}{*}{\multicolumn{3}{|c|}{$\begin{array}{l}\text { 生雪平均数 } \\
\text { 生後日数 }\end{array}$}} & \multicolumn{3}{|c|}{ 男 } & \multicolumn{3}{|c|}{ 女 } & \multicolumn{4}{|c|}{ 男 一 女 } \\
\hline & & & $\mathrm{N}_{1}$ & $\overline{\mathbf{x}}$ & $S^{2} x$ & $\mathrm{~N}_{2}$ & $\overline{\mathbf{Y}}$ & $S^{2} \mathbf{Y}$ & $\mathbf{n}$ & d & $\omega^{2}$ & $t_{0}$ \\
\hline 50 & $\sim$ & 99 & 16 & 1.57 & 6.0313 & 12 & 2.48 & 7.4399 & 26 & -0.91 & 6.6272 & -0.928 \\
\hline 100 & $\sim$ & 149 & 53 & 1.92 & 6.0008 & 36 & 1.73 & 4.3972 & 87 & 0.19 & 5.3557 & 0.381 \\
\hline 150 & $\sim$ & 199 & 75 & 1.57 & 3.3610 & 46 & 1.76 & 5.2076 & 119 & -0.19 & 4.0593 & -0.505 \\
\hline 200 & $\sim$ & 249 & 59 & 1.50 & 5.3281 & 52 & 1.69 & 2.9249 & 109 & -0.19 & 4.2037 & -0.488 \\
\hline 250 & $\sim$ & 299 & 21 & 1.89 & 3.5692 & 21 & 0.94 & 3.4300 & 40 & 0.95 & 3.4996 & 1.670 \\
\hline 300 & $\sim$ & 349 & 2 & 0.35 & 1.8052 & 1 & 0.10 & 0 & 1 & 0.25 & 1.8050 & 0.151 \\
\hline 350 & $\sim$ & 399 & 1 & 3.50 & 0 & 1 & -1.40 & 0 & 0 & 4.90 & 0 & 0 \\
\hline \multicolumn{3}{|c|}{$K=7$} & \multicolumn{10}{|c|}{$\mathrm{MR} / \mathrm{S}_{\mathrm{MR}}=0.078$} \\
\hline
\end{tabular}

口）乳歯生雪者と末生荘者の比較

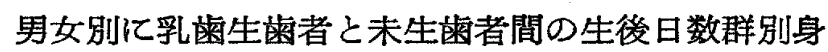
長平均発育量の差は、表16、17の通りである。
男女ともに生霜者が末生歯者よりも、身長の発育量 が大である。

表 16

男：生䨑者と未生畨者の生後日数群別身長平均発育量の差

(cm)

\begin{tabular}{|c|c|c|c|c|c|c|c|c|c|c|c|c|}
\hline \multirow{2}{*}{\multicolumn{3}{|c|}{$\begin{array}{l}\text { 生荬平均数 } \\
\text { 生啳日数 }\end{array}$}} & \multicolumn{2}{|c|}{ 生 } & \multirow{2}{*}{$\frac{\text { 者 }}{\mathbf{S}^{\mathbf{2}} \mathbf{x}}$} & \multicolumn{3}{|c|}{ 未生 雪 者 } & \multicolumn{4}{|c|}{ 生雨者 一 未生雨者 } \\
\hline & & & $\mathbf{N}_{1}$ & $\overline{\mathbf{X}}$ & & $\mathrm{N}_{2}$ & $\overline{\mathbf{Y}}$ & $\mathbf{S}^{2} \mathbf{Y}$ & $\mathbf{n}$ & d & $\omega^{2}$ & $t_{0}$ \\
\hline 50 & $\sim$ & 99 & & & & 16 & 1.57 & 6.0313 & & & & \\
\hline 100 & $\sim$ & 149 & & & & 53 & 1.92 & 6.0008 & & & & . \\
\hline 150 & $\sim$ & 199 & 21 & 2.67 & 4.3656 & 75 & 1.57 & 3.3610 & 94 & 1.10 & 3.5747 & 2.357 \\
\hline 200 & $\sim$ & 249 & 58 & 2.20 & 4.0130 & 59 & 1.50 & 5.3281 & 115 & 0.70 & 4.6763 & 1.753 \\
\hline 250 & $\sim$ & 299 & 96 & 2.39 & 4.8434 & 21 & 1.89 & 3.5692 & 115 & 0.50 & 4.6218 & 0.965 \\
\hline 300 & $\sim$ & 349 & 69 & 2.63 & 5.8295 & 2 & 0.35 & 1.8050 & 69 & 2.28 & 5.7712 & 1.321 \\
\hline 350 & $\sim$ & 399 & 31 & 1.93 & 3.9873 & 1 & 3.50 & 0 & 30 & -1.57 & 3.9873 & -0.773 \\
\hline 400 & $\sim$ & 446 & 4 & 2.65 & 8.0300 & & & & & & & \\
\hline & $\mathrm{K}=$ & & N & $\lambda=$ & & & & & & & & \\
\hline
\end{tabular}

表 17

女：生歯者と末生歯者の生後日数群別平均身長発育量の差

(cm)

\begin{tabular}{|c|c|c|c|c|c|c|c|c|c|c|c|c|}
\hline \multirow{2}{*}{\multicolumn{3}{|c|}{$\begin{array}{l}\text { 生菌平均数 } \\
\text { 生後日数 }\end{array}$}} & \multicolumn{2}{|c|}{ 生 } & \multirow{2}{*}{$\begin{array}{l}\text { 者 } \\
\mathbf{S}^{\mathbf{2}} \mathbf{x}\end{array}$} & \multicolumn{3}{|c|}{ 未 生 每 者 } & \multicolumn{4}{|c|}{ 生歯者 一 未生歯者 } \\
\hline & & & $\mathbf{N}_{1}$ & $\bar{x}$ & & $\mathrm{~N}_{2}$ & $\overline{\mathbf{Y}}$ & $\mathbf{S}^{2} \mathbf{Y}$ & $\mathbf{n}$ & d & $\omega^{2}$ & to \\
\hline 50 & $\sim$ & 99 & & & & 12 & 2.48 & 7.4399 & & & & \\
\hline 100 & $\sim$ & 149 & 1 & 2.40 & 0 & 36 & 1.73 & 4.3972 & 35 & 0.67 & 4.3972 & 0.313 \\
\hline 150 & $\sim$ & 199 & 11 & 2.05 & 2.6473 & 46 & 1.76 & 5.2076 & 55 & 0.29 & 4.7421 & 0.396 \\
\hline 200 & $\sim$ & 249 & 39 & 1.57 & 3.9618 & 52 & 1.69 & 2.9249 & 89 & -0.12 & 3.3676 & -0.308 \\
\hline 250 & $\sim$ & 299 & 59 & 2.03 & 5.2272 & 21 & 0.94 & 3.4300 & 78 & 1.09 & 4.7664 & 1.965 \\
\hline 300 & $\sim$ & 349 & 47 & 2.58 & 4.8798 & 1 & 0.10 & 0 & 46 & 2.48 & 4.8798 & 1.111 \\
\hline 350 & $\sim$ & 399 & 18 & 2.52 & 10.6140 & 1 & -1.40 & 0 & 17 & 2.66 & 10.6140 & 0.791 \\
\hline 400 & $\sim$ & 449 & 3 & 2.90 & 0.6351 & & & & & & & \\
\hline \multicolumn{3}{|c|}{$K=6$} & \multicolumn{10}{|c|}{$\mathrm{MR} / \mathrm{S}_{\mathrm{MR}}=1.591$} \\
\hline
\end{tabular}




\section{8. 乳药の生菌之体重平均発育量}

1）乳歯生電者、未生歯者の男子と女子の体重平 均発育量

乳菌の生雨者と末生雨者別に、男子と女子の生後日
数群別体重平均発育量の差は、表18、19の通りである。 生歯者及び未生霜者とも、男子と女子の体重平均発 育量の差は、はとんどない。

表 18

生霜者：男と女の生後日数群別体重平均発育量の差

$(\mathrm{Kg})$

\begin{tabular}{|c|c|c|c|c|c|c|c|c|c|c|c|}
\hline \multirow{2}{*}{\multicolumn{2}{|c|}{ 生唡平均数 }} & \multicolumn{3}{|c|}{ 男 } & \multicolumn{3}{|c|}{ 女 } & \multicolumn{4}{|c|}{ 男 一 女 } \\
\hline & & $\mathrm{N}_{\mathbf{I}}$ & $\overline{\mathbf{Y}}$ & $S^{2} x$ & $\mathrm{~N}_{2}$ & $\overline{\mathbf{Y}}$ & $S^{2} Y$ & $\mathbf{n}$ & d & $\omega^{2}$ & $t_{0}$ \\
\hline 100 & $\sim 149$ & & & & 1 & 1.00 & 0 & & & & \\
\hline 150 & $\sim 199$ & 21 & 1.72 & 1.1236 & 11 & 1.25 & 0.4653 & 30 & 0.47 & 0.9042 & 1.331 \\
\hline 200 & $\sim 249$ & 58 & 1.47 & 0.9991 & 39 & 1.19 & 0.3609 & 95 & 0.28 & 0.7438 & 1.573 \\
\hline 250 & $\sim 299$ & 96 & 1.57 & 0.7940 & 59 & 1.37 & 0.6918 & 153 & 0.20 & 0.7553 & 1.390 \\
\hline 300 & $\sim 349$ & 69 & 1.20 & 0.8400 & 48 & 1.56 & 0.7225 & 115 & -0.36 & 0.7920 & -2.152 \\
\hline 350 & $\sim 399$ & 31 & 1.59 & 0.8238 & 18 & 1.51 & 1.7978 & 47 & 0.08 & 1.1761 & 0.250 \\
\hline 400 & $\sim 449$ & 4 & 0.70 & 1. 2168 & 3 & 1.60 & 0.0100 & 5 & -0.88 & 0.7341 & -1.356 \\
\hline
\end{tabular}

表 19

末生歯者：男と女の生後日数群別体重平均発育量の差

$(\mathrm{Kg})$

\begin{tabular}{|c|c|c|c|c|c|c|c|c|c|c|c|c|}
\hline \multirow{2}{*}{\multicolumn{3}{|c|}{$\begin{array}{l}\text { 生雪平均数 } \\
\text { 生後日数 }\end{array}$}} & \multicolumn{3}{|c|}{ 男 } & \multicolumn{3}{|c|}{ 女 } & \multicolumn{4}{|c|}{ 男 一 女 } \\
\hline & & & $N_{1}$ & $\overline{\mathbf{x}}$ & $S^{2} x$ & $\mathrm{~N}_{2}$ & $\overline{\mathbf{Y}}$ & $S^{2} \mathrm{Y}$ & $\mathbf{n}$ & d & $\omega^{2}$ & $t_{o}$ \\
\hline 50 & $\sim$ & 99 & 15 & 1.07 & 0.9648 & 12 & 0.92 & 0.6145 & 25 & 0.15 & 0.8107 & 0.430 \\
\hline 100 & $\sim$ & 149 & 54 & 1.04 & 0.5240 & 36 & 1.01 & 0.3777 & 88 & 0.03 & 0.4658 & 0.205 \\
\hline 150 & $\sim$ & 199 & 75 & 1.03 & 0.7656 & 46 & 1.06 & 0.6547 & 119 & -0.03 & 0.7237 & -0.188 \\
\hline 200 & $\sim$ & 249 & 59 & 1.01 & 0.4980 & 52 & 1.06 & 0.6733 & 109 & -0.05 & 0.5800 & -0.346 \\
\hline 250 & $\sim$ & 299 & 21 & 1.33 & 0.6296 & 21 & 0.95 & 0.3854 & 40 & 0.38 & 0.5075 & 1.697 \\
\hline 300 & $\sim$ & 349 & 2 & 0.30 & 0 & 1 & 1.10 & 0 & 1 & -0.80 & 0 & 0 \\
\hline 350 & $\sim$ & 399 & 1 & 1.70 & 0 & 1 & 0.80 & 0 & 0 & 0.90 & 0 & 0 \\
\hline
\end{tabular}

$K=7$

$\mathrm{MR} / \mathrm{S}_{\mathrm{MR}}=0.630$

口）乳茵の生歯者と末生霜者の比較

男女別々乳雪の生蒾者と未生歯者間の生後日数群別 体重平均発育量の差は、表20、21の通りである。

表 20

男：生雪者亡未生亚者の生後日数群別体重平均発育量の差

男女ともに生歯者が未生歯者よりも、体重平均発育 量は大である。

\begin{tabular}{|c|c|c|c|c|c|c|c|c|c|c|c|c|}
\hline \multirow{2}{*}{\multicolumn{3}{|c|}{$\begin{array}{l}\text { 生婳正均数 } \\
\text { 生後日数 }\end{array}$}} & \multicolumn{2}{|c|}{ 生 崡 } & \multirow{2}{*}{$\begin{array}{l}\text { 者 } \\
\mathrm{S}^{2} \mathrm{x} \\
\end{array}$} & \multicolumn{3}{|c|}{ 未生 歯 者 } & \multicolumn{4}{|c|}{ 生宷者 一 未生電者 } \\
\hline & & & $\mathrm{N}_{1}$ & $\overline{\mathrm{x}}$ & & $\mathrm{N}_{2}$ & $\overline{\mathrm{Y}}$ & $\mathrm{S}^{2} \mathrm{Y}$ & \multicolumn{2}{|r|}{$\mathrm{d}$} & $\omega^{2}$ & $t_{0}$ \\
\hline 50 & $\sim$ & 99 & & & & 15 & 1.07 & 0.9648 & & & & \\
\hline 100 & $\sim$ & 149 & & & & 54 & 1.04 & 0.5240 & & & & \\
\hline 150 & $\sim$ & 199 & 21 & 1.72 & 1.1236 & 75 & 1.03 & 0.7650 & 94 & 0.69 & 0.8418 & 3.038 \\
\hline 200 & $\sim$ & 249 & 58 & 1.47 & 0.9991 & 59 & 1.01 & 0.4980 & 115 & 0.46 & 0.7464 & 2.894 \\
\hline 250 & $\sim$ & 299 & 96 & 1.57 & 0.7940 & 21 & 1.33 & 0.6296 & 115 & 0.24 & 0.7654 & 1.132 \\
\hline 300 & $\sim$ & 349 & 69 & 1.20 & 0.8400 & 2 & 0.30 & 0 & 69 & 0.90 & 0.8278 & 1.375 \\
\hline 350 & $\sim$ & 399 & 31 & 1.56 & 0.8238 & 1 & 1.70 & 0 & 30 & -0.11 & 0.8238 & -0.118 \\
\hline 400 & $\sim$ & 449 & 4 & 0.72 & 1.2168 & & & & & & & \\
\hline \multicolumn{3}{|c|}{$\mathbf{K}=5$} & \multicolumn{10}{|c|}{$M R / S_{M R}=3.328$} \\
\hline
\end{tabular}




\begin{tabular}{|c|c|c|c|c|c|c|c|c|c|c|c|c|}
\hline $\bar{\gamma}$ & 生 & 性別 & & 雪 & 者 & & 生 & 者 & & 生歯者 & 一 未生 & \\
\hline 生後日 & & 平均数 & $\mathrm{N}_{1}$ & $\bar{x}$ & $\mathrm{~S}^{2} \mathrm{x}$ & $\mathrm{N}_{2}$ & $\overline{\mathbf{Y}}$ & $\mathrm{S}^{2} \mathrm{Y}$ & $\mathbf{n}$ & d & $\omega^{2}$ & $t_{0}$ \\
\hline 50 & $\sim$ & 99 & & & & 12 & 0.92 & 0.6745 & & & & \\
\hline 100 & $\sim$ & 149 & 1 & 1.00 & 0 & 36 & 1.01 & 0.3777 & 35 & -0.01 & 0.3777 & -0.016 \\
\hline 150 & $\sim$ & 199 & 11 & 1.25 & 0.4653 & 46 & 1.06 & 0.6547 & 55 & 0.19 & 0.6203 & 0.726 \\
\hline 200 & $\sim$ & 249 & 39 & 1.19 & 0.3609 & 52 & 1.06 & 0.6733 & 89 & 0.13 & 0.5399 & 0.841 \\
\hline 250 & $\sim$ & 299 & 59 & 1.37 & 0.6918 & 21 & 0.95 & 0.3854 & 78 & 0.42 & 0.6132 & 2.116 \\
\hline 300 & $\sim$ & 349 & 48 & 1.56 & 0.7225 & 1 & 1.10 & 0 & 47 & 0.46 & 0.7225 & 0.536 \\
\hline 350 & $\sim$ & 399 & 18 & 1.51 & 1.7978 & 1 & 0.80 & 0 & 17 & 0.71 & 1.7978 & 0.514 \\
\hline 400 & $\sim$ & 449 & 3 & 1.60 & 0.0100 & & & & & & & \\
\hline & $\mathrm{K}=$ & & $\mathbf{M R}$ & $M R=$ & 758 & & & & & & & \\
\hline
\end{tabular}

\section{7. 乳画の生歯と胸囲平均発育量}

イ）乳歯生畨者と末生菌者の男女間の差 乳菡の生歯者と未生歯者別男女間の生後日数群別胸
因平均発育量の差は、表22、23の通りである。 胸囲発育量は、乳蒾の生蒾者の男女間の差はほとん に゙なく、未生䨑者は女子が男子よりも大である。

表 22

生函者：男と女の生後日数群別胸囲平均発育量の差

$(\mathrm{cm})$

\begin{tabular}{|c|c|c|c|c|c|c|c|c|c|c|c|c|}
\hline \multirow{2}{*}{\multicolumn{3}{|c|}{$\begin{array}{l}\text { 生雪平均数 } \\
\text { 生後日数 }\end{array}$}} & \multicolumn{3}{|c|}{ 男 } & \multicolumn{3}{|c|}{ 女 } & \multicolumn{4}{|c|}{ 男 一 女 } \\
\hline & & & $\mathrm{N}_{1}$ & $\mathrm{X}$ & $\mathrm{S}^{2} \mathrm{X}$ & $\mathrm{N}_{2}$ & $\mathbf{Y}$ & $S^{2} Y$ & $\mathrm{n}$ & d & $\omega^{2}$ & $t_{0}$ \\
\hline 100 & $\sim$ & & & & & 1 & 1.80 & 0 & & & & \\
\hline 150 & $\sim$ & 199 & 21 & 2.89 & 3.7312 & 11 & 2.62 & 2.9440 & 30 & 0.27 & 3.4689 & 0.390 \\
\hline 200 & $\sim$ & 249 & 58 & 3.21 & 6.0541 & 39 & 2.48 & 2.9374 & 95 & 0.73 & 4.8074 & 1.610 \\
\hline 250 & $\sim$ & 299 & 96 & 3.05 & 4.0323 & 59 & 2.47 & 5.7998 & 153 & 0.58 & 4.7023 & 1.674 \\
\hline 300 & $\sim$ & 349 & 69 & 2.22 & 3.9986 & 47 & 2.73 & 4.7024 & 114 & -0.51 & 4.2826 & -1.303 \\
\hline 350 & $\sim$ & 399 & 31 & 2.79 & 2.2534 & 18 & 2.48 & 3.3144 & 47 & 0.31 & 2.6372 & 0.645 \\
\hline 400 & $\sim$ & 449 & 4 & 2.03 & 2.7115 & 3 & 3.27 & 3.9027 & 5 & -1.24 & 3.1880 & -0.907 \\
\hline \multicolumn{3}{|c|}{$K=6$} & \multicolumn{10}{|c|}{$\mathrm{MR} / \mathrm{S}_{\mathrm{MR}_{\mathrm{R}}}=0.765$} \\
\hline
\end{tabular}

表 23

未生菡者：男と女の生後日数群別胸团平均発育量の差

$(\mathrm{cm})$

\begin{tabular}{|c|c|c|c|c|c|c|c|c|c|c|c|c|}
\hline \multirow{2}{*}{\multicolumn{3}{|c|}{ 生拳平均数 }} & \multicolumn{3}{|c|}{ 男 } & \multicolumn{3}{|c|}{ 女 } & \multicolumn{4}{|c|}{ 男 - 女 } \\
\hline & & & $\mathrm{N}_{1}$ & $\mathrm{X}$ & $\mathrm{S}^{2} \mathrm{x}$ & $\mathrm{N}_{2}$ & $\overline{\mathbf{Y}}$ & $\mathrm{S}^{2} \mathrm{Y}$ & $\mathrm{n}$ & d & $\omega^{2}$ & $t_{0}$ \\
\hline 50 & $\sim$ & 99 & 16 & 2.82 & 3.6806 & 12 & 3.01 & 2.8470 & 26 & -0.19 & 3.3279 & -0.274 \\
\hline 100 & $\sim$ & 149 & 53 & 2.62 & 6.0934 & 36 & 2.42 & 2.6471 & 87 & 0.20 & 4.7070 & 0.427 \\
\hline 150 & $\sim$ & 199 & 75 & 2.17 & 4.7637 & 46 & 2.60 & 3.7911 & 179 & -0.43 & 4.3959 & -1.093 \\
\hline 200 & $\sim$ & 249 & 59 & 2.69 & 6.1909 & $5 ?$ & 2.56 & 4.1090 & 109 & 0.13 & 5.2168 & 0.300 \\
\hline 250 & $\sim$ & 299 & 21 & 2.74 & 2.1032 & 20 & 2.37 & 2.8575 & 39 & 0.37 & 2.4707 & 0.754 \\
\hline 300 & $\sim$ & 349 & 2 & 0.05 & 0.1250 & 1 & 3.40 & 0 & 1 & -3.35 & 0.1250 & -7.753 \\
\hline 350 & $\sim$ & 399 & 1 & 4. 40 & 0 & 1 & -0.60 & 0 & 0 & 5.00 & 0 & $\cdots$ \\
\hline \multicolumn{3}{|c|}{$K=7$} & \multicolumn{10}{|c|}{$\mathrm{MR} / \mathrm{S}_{\mathrm{MR}}=-2.674$} \\
\hline
\end{tabular}


ロ）乳茵の生歯者と未生困者間の差

男女別に乳荬の生蒾者と末生菡者の胸囲発育量の差
は男子はわずが生歯者が大きく、女子は両者間の差 ははとんどない。表24、250通りである。

表 24

男：生粜者と末生雬者の生後日数群別胸囲平均発育量の差

(cm)

\begin{tabular}{|c|c|c|c|c|c|c|c|c|c|c|c|c|}
\hline \multirow{2}{*}{\multicolumn{3}{|c|}{ 生雪平均数 }} & & 菌 & 者 & & 生 & 者 & \multicolumn{4}{|c|}{ 生蒾者 一 未生歯者 } \\
\hline & & & $\mathbf{N}_{1}$ & $\bar{X}$ & $\mathbf{S}^{2} \mathbf{x}$ & $\mathrm{N}^{2}$ & $\bar{Y}$ & $\mathbf{S}^{2} \mathbf{Y}$ & $\mathbf{n}$ & d & $\omega^{2}$ & to \\
\hline 50 & $\sim$ & 99 & & & & 16 & 2.82 & 3.6806 & & & & \\
\hline 100 & $\sim$ & 149 & & & & 53 & 2.62 & 6.0934 & & & & \\
\hline 150 & $\sim$ & 199 & 21 & 2.89 & 3.7312 & 75 & 2.17 & 4.7637 & 94 & 0.72 & 4.5440 & 1.369 \\
\hline 200 & $\sim$ & 249 & 58 & 3.21 & 6.0541 & 59 & 2.69 & 6.1909 & 115 & 0.52 & 6.1231 & 1.130 \\
\hline 250 & $\sim$ & 299 & 96 & 3.05 & 4.0323 & 21 & 2.74 & 2.1032 & 115 & 0.31 & 3.6968 & 0.670 \\
\hline 300 & $\sim$ & 349 & 69 & 2.22 & 3.9986 & 2 & 0.05 & 0.1250 & 69 & 2.17 & 3.9425 & 1.516 \\
\hline 350 & $\sim$ & 399 & 31 & 2.79 & 2.2534 & 1 & 4. 40 & 0 & 30 & -1.61 & 2.2534 & -1.052 \\
\hline 400 & $\sim$ & 449 & 4 & 2.03 & 2.7115 & & & & & & & \\
\hline
\end{tabular}

$\mathbf{K}=5$

$\mathrm{MR} / \mathrm{S}_{\mathbf{M}}=1.454$

表 25

女：生歯者と未生龁者の生後日数群別胸囲平均発育量の差

$(\mathrm{cm})$

\begin{tabular}{|c|c|c|c|c|c|c|c|c|c|c|c|c|}
\hline \multirow{2}{*}{\multicolumn{3}{|c|}{$\begin{array}{l}\text { 生性別 } \\
\text { 生後日数 }\end{array}$}} & & 告 & 者 & \multicolumn{3}{|c|}{ 未生 雪 者 } & \multicolumn{4}{|c|}{ 生菌者 一未生歯者 } \\
\hline & & & $\mathbf{N}_{1}$ & $\bar{X}$ & $\mathbf{S}^{2} \mathrm{x}$ & $\mathrm{N}_{2}$ & $\overline{\mathbf{Y}}$ & $\mathbf{S}^{2} \mathbf{Y}$ & $\mathbf{n}$ & $\mathbf{b}$ & $\omega^{2}$ & $t_{o}$ \\
\hline 50 & $\sim$ & 99 & & & & 12 & 3.01 & 2.8470 & & & & \\
\hline 100 & $\sim$ & 149 & 1 & 1.80 & 0 & 36 & 2.42 & 2.6471 & 35 & -0.62 & 2.6471 & -0.373 \\
\hline 150 & $\sim$ & 199 & 11 & 2.62 & 2.9440 & 46 & 2.60 & 3.7911 & 55 & 0.02 & 3.6372 & 0.031 \\
\hline 200 & $\sim$ & 249 & 39 & 2.48 & 2.9374 & 52 & 2.56 & 4.1090 & 89 & -0.08 & 3.6088 & -0.199 \\
\hline 250 & $\sim$ & 299 & 59 & 2.47 & 5.7998 & 20 & 2.37 & 2.8575 & 77 & 0.10 & 5.0738 & 0.172 \\
\hline 300 & $\sim$ & 345 & 47 & 2.73 & 4. 7024 & 1 & 3.40 & 0 & 46 & -0.67 & 4.7024 & -0.306 \\
\hline 350 & $\sim$ & 399 & 18 & 2.48 & 3.3144 & 1 & -0.60 & 0 & 17 & 2.54 & 3.3144 & 1.354 \\
\hline 400 & $\sim$ & 449 & 3 & 3.27 & 3.9027 & & & & & & & \\
\hline
\end{tabular}

$K=5$

$\mathrm{MR} / \mathrm{S}_{\mathrm{MR}}=0.226$

8. 乳菌の生菡と頭囲平均発育量

1）男子と女子の頭囲平均発育量の比較

表 26
生紫者：男女間の生後日数群別頭囲平均発育量の差

乳歯の生歯者と未生雨者別に、男子と女子の生後日 数群別頭囲平均発育量の差は、表26、27の通りである。

\begin{tabular}{|c|c|c|c|c|c|c|c|c|c|c|c|c|}
\hline \multirow{2}{*}{\multicolumn{3}{|c|}{$\begin{array}{l}\text { 生荬平均数 } \\
\text { 生後日数 }\end{array}$}} & \multicolumn{3}{|c|}{ 男 } & \multicolumn{3}{|c|}{ 女 } & \multicolumn{4}{|c|}{ 男一女 } \\
\hline & & & $\mathrm{N}_{1}$ & $\bar{X}$ & $\mathbf{S}_{2 x}$ & $\mathrm{~N}^{2}$ & $\overline{\mathbf{Y}}$ & $S^{2} \mathbf{Y}$ & $\mathbf{n}$ & d & $\omega^{2}$ & $t_{0}$ \\
\hline 100 & $\sim$ & 149 & & & & 1 & 1.90 & 0 & & & & \\
\hline 150 & $\sim$ & 199 & 21 & 1.03 & 1.2154 & 11 & 0.53 & 0.4700 & 30 & 0.50 & 0.9669 & 1.372 \\
\hline 200 & $\sim$ & 249 & 58 & 0.99 & 1.2981 & 39 & 0.71 & 0.8326 & 95 & 0.28 & 1.1119 & 1.288 \\
\hline 250 & $\sim$ & 299 & 96 & 1.54 & 1.7967 & 59 & 0.91 & 1.4024 & 153 & 0.63 & 1.6472 & 2.973 \\
\hline 300 & $\sim$ & 349 & 69 & 1.21 & 2.3101 & 48 & 1.12 & 1.1755 & 115 & 0.09 & 1.8464 & 0.352 \\
\hline 350 & $\sim$ & 399 & 31 & 1.17 & 2.9567 & 18 & 1.11 & 2.2719 & 47 & 0.06 & 2.7090 & 0.123 \\
\hline 400 & $\sim$ & 449 & 4 & 2.43 & 5.8395 & 3 & 1.20 & 0.3700 & 5 & 1.23 & 3.6517 & 0.844 \\
\hline \multicolumn{3}{|c|}{$K=6$} & \multicolumn{10}{|c|}{$\mathrm{MR} / \mathrm{S}_{\mathrm{MR}_{\mathrm{R}}}=2.593$} \\
\hline
\end{tabular}




\begin{tabular}{|c|c|c|c|c|c|c|c|c|c|c|c|c|}
\hline \multirow{2}{*}{\multicolumn{3}{|c|}{$\begin{array}{l}\text { 生歯平均数 } \\
\text { 生後日数 }\end{array}$}} & \multicolumn{3}{|c|}{ 男 } & \multicolumn{3}{|c|}{ 女 } & \multicolumn{4}{|c|}{ 男 一 女 } \\
\hline & & & $\mathrm{N}_{1}$ & $\bar{X}$ & $S^{2} \mathrm{X}$ & $\mathrm{N}_{2}$ & $\mathbf{Y}$ & $\mathbf{S}^{2} \mathbf{Y}$ & $\mathbf{n}$ & d & $\omega^{2}$ & $t_{0}$ \\
\hline 50 & $\sim$ & 99 & 16 & 0.84 & 0.7830 & 12 & 1.90 & 1.8310 & 26 & -1.06 & 1.2264 & -2.502 \\
\hline 100 & $\sim$ & 149 & 54 & 0.19 & 1.6804 & 36 & 0.79 & 0.9465 & 88 & -0.68 & 1.3885 & -2.680 \\
\hline 150 & $\sim$ & 199 & 75 & 0.66 & 1.4992 & 46 & 0.86 & 1.4722 & 119 & -0.20 & 1.4890 & -0.125 \\
\hline 200 & $\sim$ & 249 & 59 & 0.85 & 1.2752 & 52 & 0.93 & 1.5849 & 109 & -0.08 & 1.4201 & -0.354 \\
\hline 250 & $\sim$ & 299 & 21 & 1.34 & 1.7313 & 21 & 0.59 & 0.6979 & 40 & 0.75 & 1.2146 & 2.161 \\
\hline 300 & $\sim$ & 349 & 2 & 0.50 & 8.0000 & 1 & 0.90 & 0 & 1 & -0.40 & 8.0000 & -0.114 \\
\hline 350 & $\sim$ & 399 & 1 & 0.50 & 0 & 1 & 0.40 & 0 & 0 & 0.10 & 0 & 0 \\
\hline
\end{tabular}

生歯者は男子が女子よりも頭囲平均発育量が大さく 未生歯者は逆に女子の方が男子よりもわずかに大であ る。
ロ）乳荬の生雬者と未生粷者との比較

男女別に乳蒾の生歯者と末生歯者間の生後日数群別 頭团平均発育量の差は、表28、29の通りである。

表 28

男：生雪者と未生菡者の生後日数群別頭囲平均発育量の差

(cm)

\begin{tabular}{|c|c|c|c|c|c|c|c|c|c|c|c|c|}
\hline \multirow{2}{*}{\multicolumn{3}{|c|}{ 生困平均数 }} & \multicolumn{2}{|c|}{ 生 } & \multirow{2}{*}{$\begin{array}{l}\text { 者 } \\
\mathrm{S}^{2} \mathrm{X}\end{array}$} & \multicolumn{3}{|c|}{ 未生曾 者 } & \multicolumn{4}{|c|}{ 生畨者 一 末生栽者 } \\
\hline & & & $\mathbf{N}_{1}$ & $\overline{\mathbf{X}}$ & & \multirow{2}{*}{$\frac{\mathrm{N}_{2}}{16}$} & \multirow{2}{*}{$\frac{\overline{\mathbf{Y}}}{0.84}$} & $S^{2} Y$ & $\mathbf{n}$ & $d$ & $\omega^{2}$ & $t_{0}$ \\
\hline 50 & $\sim$ & 99 & & & & & & 0.7830 & & & & \\
\hline 100 & $\sim$ & 149 & & & & 54 & 0.19 & 1.6804 & & & & \\
\hline 150 & $\sim$ & 199 & 21 & 1.03 & 1.2154 & 75 & 0.66 & 1.4992 & 94 & 0.37 & 1.4388 & 1.249 \\
\hline 200 & $\sim$ & 249 & 58 & 0.99 & 1.2981 & 59 & 0.85 & 1.2752 & 115 & 0.14 & 1.2866 & 0.670 \\
\hline 250 & $\sim$ & 299 & 96 & 1.54 & 1.7967 & 21 & 1.34 & 1.7313 & 115 & 0.20 & 1.7853 & 0.619 \\
\hline 300 & $\sim$ & 349 & 69 & 1.21 & 2.3101 & 2 & 0.50 & 8.0000 & 69 & 0.71 & 2.3926 & 0.637 \\
\hline 350 & $\sim$ & 399 & 31 & 1.17 & 2.9567 & 1 & 0.50 & 0 & 30 & 0.67 & 2.9567 & 0.382 \\
\hline 400 & $\sim$ & 449 & 4 & 2.43 & 5.8395 & & & & & & & \\
\hline \multicolumn{3}{|c|}{$K=5$} & \multicolumn{10}{|c|}{$\mathbf{M R} / \mathbf{S}_{\mathbf{R} R}=1.422$} \\
\hline
\end{tabular}

表 29

女：生歯者と未生蒾者の生後日数群別頭囲平均発育量の差

(cm)

\begin{tabular}{|c|c|c|c|c|c|c|c|c|c|c|c|c|}
\hline \multirow{2}{*}{\multicolumn{3}{|c|}{ 生整平均数 }} & & 梷 & 者 & \multirow{2}{*}{\multicolumn{3}{|c|}{\begin{tabular}{l|l|l}
\multicolumn{2}{c}{ 未 } & 生 歯 者 \\
$\mathbf{N}_{\mathbf{2}}$ & $\overline{\mathrm{Y}}$ & $\mathbf{S}^{\mathbf{2}} \mathbf{Y}$
\end{tabular}}} & \multicolumn{4}{|c|}{ 生歯者 一 未生畨者 } \\
\hline & & & $\mathbf{N}_{\mathbf{1}}$ & $\overline{\mathrm{X}}$ & $S^{2} x$ & & & & $\mathbf{n}$ & d & $\omega^{2}$ & $t_{0}$ \\
\hline 50 & $\sim$ & 99 & & & & 12 & 1.90 & 1.8310 & & & & \\
\hline 100 & $\sim$ & 149 & 1 & 1.90 & 0 & 36 & 0.79 & 0.9465 & 35 & 1.11 & 0.9465 & 1.121 \\
\hline 150 & $\sim$ & 199 & 11 & 0.53 & 0.4700 & 46 & 0.86 & 1.4722 & 55 & --0.33 & 1.2900 & -0.863 \\
\hline 200 & $\sim$ & 249 & 39 & 0.71 & 0.8326 & 52 & 0.93 & 1.5849 & 89 & -0.22 & 1.2637 & -0.927 \\
\hline 250 & $\sim$ & 299 & 59 & 0.91 & 1.4024 & 21 & 0.59 & 0.6979 & 78 & 0.36 & 1.2218 & 1.275 \\
\hline 300 & $\sim$ & 349 & 48 & 1.12 & 1.1755 & 1 & 0.90 & 0.6979 & 47 & 0.22 & 1.1755 & 0.202 \\
\hline 350 & $\sim$ & 399 & 18 & 1.11 & 2.2719 & 1 & 0.40 & 0 & 17 & 0.71 & 2.2719 & 0.456 \\
\hline 400 & $\sim$ & 449 & 3 & 1.20 & 0.3700 & & & 0 & & & & \\
\hline \multicolumn{3}{|c|}{$K=6$} & \multicolumn{10}{|c|}{$\mathrm{MR} / \mathrm{S}_{\mathrm{MR}}=0.472$} \\
\hline
\end{tabular}


男女とも生歯者と未生霜者間の頭囲平均発育量の差 は著しくない。

\section{9. 乳歯の生歯と両親平均身長}

1）男子と女子の両親平均身長の比較

表 30

生菌者：男と女の生後日数群別両親平均身長の差

\begin{tabular}{|c|c|c|c|c|c|c|c|c|c|c|c|c|}
\hline \multirow{2}{*}{\multicolumn{3}{|c|}{$\begin{array}{l}\text { 生蒾平均数 } \\
\text { 生後日数 }\end{array}$}} & \multicolumn{3}{|c|}{ 男 } & \multicolumn{3}{|c|}{ 女 } & \multicolumn{4}{|c|}{ 男 - 女 } \\
\hline & & & $\mathrm{N}_{1}$ & $\overline{\mathbf{x}}$ & $S^{2} x$ & $\mathrm{~N}_{2}$ & $\overline{\mathrm{Y}}$ & $S^{2} Y$ & $\mathbf{n}$ & d & $\omega^{2}$ & $t_{0}$ \\
\hline 100 & $\sim$ & 149 & & & & 1 & 323.00 & 0 & & & & \\
\hline 150 & $\sim$ & 199 & 21 & 324.71 & 29.1117 & 11 & 325.27 & 57.6258 & 30 & -0.56 & 38.6164 & -0.243 \\
\hline 200 & $\sim$ & 249 & 50 & 321.36 & 69.5412 & 34 & 320.88 & 63.9755 & 82 & 0.48 & 67.3013 & 0.263 \\
\hline 250 & $\sim$ & 299 & 86 & 321.98 & 65.7172 & 54 & 319.96 & 38.6399 & 138 & 2.02 & 55.3179 & 1.564 \\
\hline 300 & $\sim$ & 349 & 63 & 322.43 & 40.4440 & 45 & 323.76 & 62.9638 & 106 & -1.33 & 49.7918 & -0.965 \\
\hline 350 & $\sim$ & 399 & 29 & 322.52 & 51.8439 & 17 & 324.59 & 57.6301 & 44 & -2.07 & 53.9480 & -0.921 \\
\hline 400 & $\sim$ & 449 & $\therefore 4$ & 318.00 & 14.0000 & 3 & 318.67 & 52.2967 & 5 & -0.67 & 29.3187 & -0.162 \\
\hline
\end{tabular}

$\mathrm{K}=6$

$\mathrm{MR} / \mathrm{S}_{\mathrm{MR}}=-0.172$
乳菌の生宷者と未生歯者別に、男子と女子の生後日 数群別両親平均身長の差は、表30、310通りで、生䨑 者、及び未生雪者ともに両親平均身長の差はほとんど ない。

$(\mathrm{cm})$

表 31 未生䨑者：男と女の生後日数群別両親平均身長の差

$(\mathrm{cm})$

\begin{tabular}{|c|c|c|c|c|c|c|c|c|c|c|c|c|}
\hline \multirow{2}{*}{\multicolumn{3}{|c|}{$\begin{array}{l}\text { 生零平均数 } \\
\text { 生後日数 }\end{array}$}} & \multicolumn{3}{|c|}{ 男 } & \multicolumn{3}{|c|}{ 女 } & \multicolumn{4}{|c|}{ 男 一 女 } \\
\hline & & & $\mathrm{N}_{1}$ & $\bar{x}$ & $S^{2} x$ & $\mathrm{~N}_{2}$ & $\overline{\mathrm{Y}}$ & $S^{2}{ }_{Y}$ & $\mathbf{n}$ & $\mathrm{d}$ & $\omega^{2}$ & $t_{0}$ \\
\hline 50 & $\sim$ & 99 & 15 & 318.87 & 49.9748 & 11 & 319.91 & 18.0891 & 24 & -1.04 & 36.6891 & -0.432 \\
\hline 100 & $\sim$ & 149 & 51 & $320 \cdot 24$ & 45.3116 & 34 & 323.00 & 78.4242 & 83 & -2.76 & 58.4769 & -1.631 \\
\hline 150 & $\sim$ & 199 & 66 & 320.83 & 54.7313 & 40 & 321.90 & 52.1949 & 104 & -1.07 & 53.7802 & -0.728 \\
\hline 200 & $\sim$ & 249 & 55 & 319.91 & 57.3418 & 47 & 321.74 & 47.6744 & .100 & -1.83 & 50.1072 & -1.300 \\
\hline 250 & $\sim$ & 299 & 18 & 321.00 & 38.9412 & 21 & 320.71 & 25.1027 & 37 & 0.29 & 31.4609 & 0.161 \\
\hline 300 & $\sim$ & 349 & 1 & 318.00 & 0 & 1 & 330.00 & 0 & 0 & -12.00 & 0 & 0 \\
\hline 350 & $\sim$ & 399 & 1 & 324.00 & 0 & 1 & 312.00 & 0 & 0 & 12.00 & 0 & 0 \\
\hline
\end{tabular}

口) 乳蒾の生歯者と末生歯者との比較

男女別江乳蒾の生菊者と末生歯者間の生後日数群別
両親平均身長の差を比較すれば、表 32、33の通りで ある。

表 32 男: 生歯者と末生歯者の生後日数群別両親平均身長の差

$(\mathrm{cm})$

\begin{tabular}{|c|c|c|c|c|c|c|c|c|c|c|c|c|}
\hline \multirow{2}{*}{\multicolumn{3}{|c|}{ 生歯平均数 }} & \multicolumn{2}{|c|}{ 生 歯 } & \multirow{2}{*}{$\frac{\text { 者 }}{S^{2} \mathrm{X}}$} & \multicolumn{3}{|c|}{ 末 生 歯 者 } & \multicolumn{4}{|c|}{ 生 崡 者一未生歯者 } \\
\hline & & & $\mathbf{N}_{1}$ & $\overline{\mathrm{x}}$ & & $\mathrm{N}_{2}$ & $\overline{\bar{Y}}$ & $S^{2} \mathrm{Y}$ & $\mathrm{n}$ & d & $\omega^{2}$ & $t_{o}$ \\
\hline 50 & $\sim$ & 99 & & & & 15 & 318.87 & 49.9748 & & & & . \\
\hline 100 & $\sim$ & 149 & & & & 51 & 320.24 & 176 & & & & \\
\hline 150 & $\sim$ & 199 & 21 & 324.71 & 29.1117 & 66 & 320.83 & 54.7313 & 85 & 3.88 & 48.7032 & 2.218 \\
\hline 200 & $\sim$ & 249 & 50 & 321.36 & 69.5412 & 55 & 319.91 & 57.3418 & 103 & 1.45 & 63.7454 & 0.934 \\
\hline 250 & $\sim$ & 299 & 86 & 321.98 & 65.7172 & 18 & 321.00 & 38.9412 & 102 & 0.98 & 61.2545 & 0.483 \\
\hline 300 & $\sim$ & 349 & 63 & 322.43 & 40.4440 & 1 & 318.00 & 0 & 62 & 4.43 & 40.4440 & 0.690 \\
\hline 350 & $\sim$ & 399 & 29 & 322.52 & 51.8439 & 1 & 324.00 & 0 & 28 & -1.48 & 51.8439 & -0.201 \\
\hline 400 & $\sim$ & 449 & 4 & 318.00 & 14.0000 & & & & & & & \\
\hline & $\mathbf{n}=$ & & $1 \mathrm{VII}$ & M & & & & & & & & \\
\hline
\end{tabular}




\begin{tabular}{|c|c|c|c|c|c|c|c|c|c|c|c|c|}
\hline \multirow{2}{*}{\multicolumn{3}{|c|}{ 生崡平均数 }} & \multicolumn{2}{|r|}{ 生 菌 } & \multirow{2}{*}{$\begin{array}{l}\text { 者 } \\
S^{2}{ }^{x}\end{array}$} & \multicolumn{3}{|c|}{ 未 生 歯 者 } & \multicolumn{4}{|c|}{ 生 雪 者一未生歯者 } \\
\hline & & & $\mathrm{N}_{1}$ & $\overline{\mathrm{x}}$ & & $\mathrm{N}_{2}$ & $\overline{\mathbf{Y}}$ & $S^{2} \mathrm{Y}$ & $\mathbf{n}$ & d & $\omega^{2}$ & $t_{o}$ \\
\hline 50 & $\sim$ & 99 & & & & 11 & 319.91 & 18.0891 & 3 & & & \\
\hline 100 & $\sim$ & 149 & 1 & 323.00 & 0 & 34 & 323.00 & 78.4242 & 33 & 0 & 78.4242 & 0 \\
\hline 150 & $\sim$ & 199 & 11 & 325.27 & 57.6258 & 40 & 321.90 & 52.1949 & 49 & 3.37 & 53.3032 & 1.357 \\
\hline 200 & $\sim$ & 249 & 34 & 320.88 & 63.9755 & 47 & $32 \mathrm{~L} .74$ & 41.6144 & 79 & -0.86 & 50.9551 & -0.535 \\
\hline 250 & $\sim$ & 299 & 54 & 319.96 & 38.6399 & 21 & 320.71 & $25 \cdot 1027$ & 73 & -0.75 & 34.9311 & -0.494 \\
\hline 300 & $\sim$ & 349 & 45 & 323.76 & 62.9638 & 1 & 330.00 & 0 & 44 & -6.24 & 62.9638 & -0.771 \\
\hline 350 & $\sim$ & 499 & 17 & 324.59 & 57.6301 & 1 & 312.00 & 0 & 16 & 12.59 & 57.6301 & 1.609 \\
\hline 400 & $\sim$ & 449 & 3 & 318.67 & 52.2967 & & & & & & & \\
\hline
\end{tabular}

男子は生荬者が未生霜者よりも両親の平均身長がや や大で、女子は両者間の差はない。

10. 乳蒾の生歯と両親の平均体重

1）男子と女子の而親平均体重の比較
乳蒾の生雪者と未生霜者別に、男子と女子の生後日 数群別両䅐平均体重の差は表34、350通りで、生匀者 は男女間の差ははとんどなく、未生歯者は女子が男子 よりやや大である。

表 34

生菌者：男と女の生後日数群別両親（父十母）の平均体重の差

(kg)

\begin{tabular}{|c|c|c|c|c|c|c|c|c|c|c|c|c|}
\hline \multirow{2}{*}{\multicolumn{3}{|c|}{ 生䨝平均数 }} & \multicolumn{3}{|c|}{ 男 } & \multicolumn{3}{|c|}{ 女 } & \multicolumn{4}{|c|}{ 男 一 女 } \\
\hline & & & $\mathrm{N}_{1}$ & $\mathrm{x}$ & $S^{2} x$ & $\mathrm{~N}_{2}$ & $\mathbf{Y}$ & $S^{2} Y$ & $\mathbf{n}$ & d & $\omega^{2}$ & $t_{o}$ \\
\hline 100 & $\sim$ & 149 & & & & 1 & 117.00 & 0 & & & & \\
\hline 150 & $\sim$ & 199 & 19 & 115.21 & 58.2868 & 10 & 111.10 & 76.9889 & 27 & 4.11 & 64.5208 & 1.310 \\
\hline 200 & $\sim$ & 249 & 49 & 110.65 & 131.4708 & 33 & 109.91 & 114.9585 & 80 & 0.74 & 124.8659 & 0.294 \\
\hline 250 & $\sim$ & 299 & 83 & 112.77 & 103.1050 & 52 & 112.44 & 99.1555 & 133 & 0.33 & 101.5905 & 0.185 \\
\hline 300 & $\sim$ & 349 & 58 & 112.47 & 84.8103 & 45 & 112.27 & 124.9254 & 101 & 0.20 & 102.2862 & 0.100 \\
\hline 350 & $\sim$ & 399 & 28 & 109.52 & 66.2212 & 15 & 113.80 & 99.3143 & 41 & -4.28 & 77.5213 & -1.522 \\
\hline 400 & $\sim$ & 449 & 4 & 110.25 & 71.5833 & 3 & 116.00 & 84.0000 & 5 & -5.48 & 76.5500 & -0.820 \\
\hline
\end{tabular}

表 35

未生歯者：男と女の生後日数群別両親平均体重の差

( $\mathrm{kg})$

\begin{tabular}{|c|c|c|c|c|c|c|c|c|c|c|c|c|}
\hline \multirow{2}{*}{\multicolumn{3}{|c|}{$\begin{array}{l}\text { 生電平均数 } \\
\text { 生後日数 }\end{array}$}} & \multicolumn{3}{|c|}{ 男 } & \multicolumn{3}{|c|}{ 女 } & \multicolumn{4}{|c|}{ 男 一 女 } \\
\hline & & & $\mathrm{N}_{1}$ & $\mathrm{x}$ & $\mathrm{S}^{2} \mathrm{x}$ & $\mathrm{N}_{2}$ & $\mathbf{Y}$ & $S^{2} \mathrm{Y}$ & $\mathrm{n}$ & d & $\omega^{2}$ & $t_{0}$ \\
\hline 50 & $\sim$ & 99 & 12 & 107.00 & 56.7273 & 10 & 170.30 & 97.1222 & 20 & -3.30 & 74.9050 & -0.893 \\
\hline 100 & $\sim$ & 149 & 49 & 111.92 & 60.8651 & 32 & 114.13 & 106.4987 & 79 & -2.21 & 78.7720 & -1.095 \\
\hline 150 & $\sim$ & 199 & 64 & 110.39 & 83.8296 & 41 & 171.95 & 137.8524 & 103 & -1.56 & 104.8093 & -0.762 \\
\hline 200 & $\sim$ & 249 & 52 & 111.62 & 99.8732 & 43 & 113.30 & 117.2269 & 93 & -1.68 & 107.7105 & -0.785 \\
\hline 250 & $\sim$ & 299 & 17 & 109.94 & 89.1837 & 21 & 112.10 & 51.7895 & 36 & -2.16 & 68.4091 & -0.802 \\
\hline 300 & $\sim$ & 349 & & & & 1 & 121.00 & 0 & & & & $\therefore$ \\
\hline 350 & $\sim$ & 399 & & & & 1 & 105.00 & 0 & & & & \\
\hline
\end{tabular}


口）乳柬の生雨者と末生菌者との比較男女別て、 均体重の差は、表36、37の通りである。

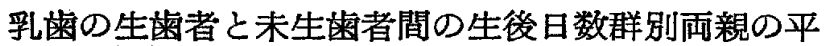

表 36

男: 生雬者と末生歯者の生後日数群別両親（父十母）の平均体重の差

(kg)

\begin{tabular}{|c|c|c|c|c|c|c|c|c|c|c|c|c|}
\hline \multirow{2}{*}{\multicolumn{3}{|c|}{ 生後性数 }} & \multicolumn{2}{|c|}{ 生 } & \multirow{2}{*}{$S^{2} x$} & \multicolumn{3}{|c|}{ 未 生 稳 者 } & \multicolumn{4}{|c|}{ 生 電 者 一 未生柬者 } \\
\hline & & & $\mathbf{N}_{1}$ & $\bar{X}$ & & $\mathrm{~N}_{2}$ & $\overline{\mathbf{Y}}$ & $\mathbf{S}^{2} \mathbf{Y}$ & $\mathbf{n}$ & d & $\omega^{2}$ & $t_{o}$ \\
\hline 50 & $\sim$ & 99 & & & & 12 & 107.00 & 56.7273 & & & & \\
\hline 100 & $\sim$ & 149 & & & & 49 & 111.92 & 60.8651 & & & & \\
\hline 150 & $\sim$ & 199 & 19 & 115.21 & 58.2868 & 64 & 110.39 & 83.8296 & 81 & 4.82 & 78.1534 & 2.088 \\
\hline 200 & $\sim$ & 249 & 49 & 110.65 & 131.4708 & 52 & 111.62 & 99.8732 & 99 & 0.97 & 115.1932 & -0.454 \\
\hline 250 & $\sim$ & 299 & 83 & 112.77 & 103.1050 & 17 & 109.94 & 89.1837 & 98 & 2.83 & 100.8321 & 1.060 \\
\hline 300 & $\sim$ & 349 & 58 & 112.47 & 84.8103 & & & & & & & \\
\hline 350 & $\sim$ & 399 & 28 & 109.52 & 66.2212 & & & & & & & \\
\hline 400 & $\sim$ & 449 & 4 & 110.25 & 71.5833 & & & & & & & \\
\hline \multicolumn{3}{|c|}{$\mathbf{K}=3$} & \multicolumn{10}{|c|}{$\mathrm{MR} / \mathrm{S}_{\mathbf{M R}}=1.270$} \\
\hline
\end{tabular}

表 37

女：生雪者と末生畨者の生後日数群別両親（父+母）の平均体重の差

(kg)

\begin{tabular}{|c|c|c|c|c|c|c|c|c|c|c|c|c|}
\hline \multirow{2}{*}{\multicolumn{3}{|c|}{ 生雪平均数 }} & & 畨 & 者 & \multicolumn{3}{|c|}{ 未生 菌 者 } & \multicolumn{4}{|c|}{ 生 畨 者一未生粷者 } \\
\hline & & & $\mathrm{N}_{1}$ & $\overline{\mathbf{X}}$ & $\mathbf{S}^{2} \mathrm{X}$ & $\mathrm{N}_{2}$ & $\overline{\mathbf{Y}}$ & $\mathbf{S}^{2} \mathbf{Y}$ & $\mathbf{n}$ & d & $\omega^{2}$ & to \\
\hline 50 & $\sim$ & 99 & & & & 10 & 110.30 & 97.1222 & & & & \\
\hline 100 & $\sim$ & 149 & 1 & 117.00 & 0 & 32 & 114.13 & 106.4987 & 31 & 2.87 & 106.4987 & 0.273 \\
\hline 150 & $\sim$ & 199 & 10 & 111.10 & 76.9889 & 41 & 111.95 & 137.8524 & 49 & -0.85 & 126.6734 & -0.215 \\
\hline 200 & $\sim$ & 249 & 33 & 109.91 & 114.9585 & 43 & 113.30 & 117.2269 & 74 & -3.39 & 116.2460 & -1.356 \\
\hline 250 & $\sim$ & 299 & 52 & 112.44 & 99.1555 & 21 & 112.10 & 51.7895 & 71 & 0.24 & 85.8130 & 0.100 \\
\hline 300 & $\sim$ & 349 & 45 & 112.27 & 124.9254 & 1 & 121.00 & 0 & 44 & -8.73 & 124.9254 & -0.765 \\
\hline 350 & $\sim$ & 399 & 15 & 113.80 & 99.3143 & 1 & 105.00 & 0 & 14 & 8.80 & 99.3143 & 0.847 \\
\hline 400 & $\sim$ & 496 & 3 & 116.00 & 84.0000 & & & & & & & \\
\hline
\end{tabular}

$\mathbf{K}=6$

$\mathrm{MR} / \mathrm{S}_{\mathbf{M M}}=-0.416$ ない。

男女とも乳米の生荬者と未生苗者間の差はほとんど

11. 乳審の生露と母の年令

イ）男子と女子との母の年令の比較

生省者と末生娄者別に、男子と女子の生後日数群別 母の年令を比べると、表38、390通りである。

表 38 生雪者：男と女の生後日数群別母の平均年令の差

(才)

\begin{tabular}{|c|c|c|c|c|c|c|c|c|c|c|c|c|}
\hline \multirow{2}{*}{\multicolumn{3}{|c|}{$\begin{array}{l}\text { 生菌平均数 } \\
\text { 生後日数 }\end{array}$}} & \multicolumn{3}{|c|}{ 男 } & \multicolumn{3}{|c|}{ 女 } & \multicolumn{2}{|r|}{ 男 } & \multicolumn{2}{|l|}{ 女 } \\
\hline & & & \multirow[t]{2}{*}{$\mathbf{N}_{1}$} & \multirow[t]{2}{*}{$\overline{\mathbf{X}}$} & \multirow[t]{2}{*}{$\mathrm{S}^{2} \mathrm{x}$} & \multirow{2}{*}{$\frac{\mathrm{N}_{2}}{1}$} & \multirow{2}{*}{$\frac{\bar{Y}}{26.00}$} & \multirow{2}{*}{$\frac{S^{\mathbf{x}_{\mathbf{Y}}}}{0}$} & \multirow[t]{2}{*}{$\mathbf{n}$} & \multirow[t]{2}{*}{ d } & \multirow[t]{2}{*}{$\omega_{2}$} & \multirow[t]{2}{*}{$t_{o}$} \\
\hline 100 & $\sim$ & 149 & & & & & & & & & & \\
\hline 150 & $\sim$ & 199 & 21 & 27.14 & 10.4294 & 11 & 26.09 & 16.4891 & 30 & 1.05 & 12.4493 & 0.800 \\
\hline 200 & $\sim$ & 249 & 58 & 20.76 & 14.7133 & 38 & 26.21 & 5.7925 & 94 & 0.55 & 11.2019 & 0.786 \\
\hline 250 & $\sim$ & 299 & 96 & 27.36 & 13.9545 & 58 & 26.53 & 6.4503 & 152 & 0.83 & 11.1404 & 1.494 \\
\hline 300 & $\sim$ & 349 & 69 & 26.52 & 11.3103 & 48 & 25.73 & 8.4770 & 115 & 0.79 & 10.7523 & 1.317 \\
\hline 350 & $\sim$ & 399 & 30 & 26.47 & .15 .1508 & 18 & 27.06 & 5.9374 & 46 & -0.59 & 11.7458 & -0.578 \\
\hline 400 & $\sim$ & 449 & 4 & 25.00 & 6.0000 & 3 & 25.33 & 4. 3267 & 5 & -0.33 & 5.3307 & -0.187 \\
\hline & 計 & & 278 & 26.88 & 13.1851 & 177 & 26.24 & 7.3341 & 453 & 0.64 & 10.9119 & 2.017 \\
\hline
\end{tabular}

\begin{tabular}{l|l}
$\mathbf{K}=6$ & $\mathrm{MR} / \mathrm{MR}=1.362$
\end{tabular} 
表 39

未生雪者: 男と女の生後日数群別母の平均年令の差

(才)

\begin{tabular}{|c|c|c|c|c|c|c|c|c|c|c|c|c|}
\hline \multirow{2}{*}{\multicolumn{3}{|c|}{ 生雪平均数 }} & \multicolumn{3}{|c|}{ 男 } & \multicolumn{3}{|c|}{ 女 } & \multicolumn{4}{|c|}{ 男 - 女 } \\
\hline & & & $\mathrm{N}_{1}$ & $\bar{x}$ & $S^{2} x$ & $\mathrm{~N}_{2}$ & $\overline{\mathbf{Y}}$ & $S^{2} Y$ & $\mathbf{n}$ & d & $\omega^{2}$ & $t_{0}$ \\
\hline 50 & $\sim$ & 99 & 15 & 26.13 & 5.1248 & 12 & 27.17 & 14.7030 & 25 & -1.04 & 9.3392 & -0.877 \\
\hline 100 & $\sim$ & 149 & 54 & 26.70 & 0.8882 & 36 & 25.28 & 9.9811 & 88 & 1.42 & 4.5047 & 3. 115 \\
\hline 150 & $\sim$ & 199 & 75 & 26.76 & 11.1578 & 45 & 27.20 & 12.1182 & 118 & -0.34 & 11.5159 & -0.532 \\
\hline 200 & $\sim$ & 249 & 59 & $27 \cdot 10$ & 10.5071 & 52 & 27.54 & 15.7419 & 109 & -0.44 & 12.9564 & -0.643 \\
\hline 250 & $\sim$ & 299 & 21 & 26.57 & 9.2559 & 21 & 26.90 & 8.1995 & 40 & -0.33 & 8.7277 & -0.362 \\
\hline 300 & $\sim$ & 349 & 2 & 23.50 & 24.5000 & 1 & 29.00 & 0 & 1 & -5.50. & 24.5000 & -0.900 \\
\hline 350 & $\sim$ & 399 & 1 & 27.00 & 0 & 1 & 31.00 & 0 & 0 & -400 & $\therefore \quad 0$ & 0 \\
\hline & 計 & & 227 & 26.79 & 10.2119 & 168 & 26.85 & 12.8791 & 393 & -0.06 & 11.3453 & $\div 0.175$ \\
\hline & $\mathbf{R}=$ & & 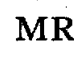 & 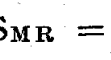 & & & & & & & & \\
\hline
\end{tabular}

生曾者の母の平均年令は男子が女子よりもわずが 多い。未生歯者は男と女の間に母の年令の差はほとん どない。

表 40

男：生雪者と未生歯者の生後日数群別母平均年令の差

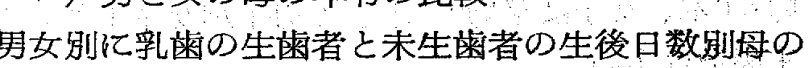
平均年令を比べると、

\begin{tabular}{|c|c|c|c|c|c|c|c|c|c|c|c|c|}
\hline \multirow{2}{*}{\multicolumn{3}{|c|}{$\begin{array}{l}\text { 生雷平均数 } \\
\text { 生後日数 }\end{array}$}} & \multirow{2}{*}{$\begin{array}{l}\text { 生 } \\
\mathrm{N}_{1}\end{array}$} & 歯 & \multirow{2}{*}{$\frac{\text { 者 }}{S^{2}{ }_{X}}$} & \multicolumn{3}{|c|}{ 未生 歯 者 } & \multicolumn{4}{|c|}{ 生 荬 者一未生窭者 } \\
\hline & & & & $\bar{x}$ & & $\mathrm{~N}_{2}$ & $\overline{\mathbf{Y}}$ & $S^{2} \mathrm{Y}$ & $\mathbf{n}$ & c & $\omega^{2}$ & $t_{0}$ \\
\hline 50 & $\sim$ & 99 & & & & 15 & 26.13 & 5.1248 & & & & \\
\hline 100 & $\sim$ & 149 & & & & 54 & 26.70 & 0.8 & & & & \\
\hline 150 & $\sim$ & 199 & 21 & 27.14 & 10.4294 & 75 & 26.76 & 11.1578 & 94 & 0.38 & 11.0028 & 0.464 \\
\hline 200 & $\sim$ & 249 & 58 & 26.76 & 14. & 59 & $27 \cdot 10$ & 10.5071 & 115 & -0.34 & 12.5919 & -0.518 \\
\hline 250 & $\sim$ & 299 & 96 & 27.36 & 13.9545 & 21 & 26.57 & 9.2559 & 175 & 0.79 & 13. 1374 & 0.906 \\
\hline 300 & $\sim$ & 349 & 69 & 26.52 & 11 . & 2 & 23.50 & 24.5000 & 69 & 3.02 & 11.5015 & 1.238 \\
\hline 350 & $\sim$ & 399 & 30 & 26.47 & 15.1508 & 1 & 27.00 & & 29 & -0.53 & $15 \cdot 1508$ & -0.134 \\
\hline 400 & $\sim$ & 449 & 4 & 25.00 & 000 & & & & & & & \\
\hline & 計 & & 278 & 26.88 & 13. 1851 & 227 & 26.79 & 10.2119 & 50.3 & 0.09 & $11 . .8492$ & 0.293 \\
\hline
\end{tabular}

$\mathbf{K}=6$

$\mathrm{MR} / \mathrm{S}_{\mathrm{MR}}=0.839$

表 41

女：生霜者と末生䨑者の生後日数群别母平均年令の差

(才)

\begin{tabular}{|c|c|c|c|c|c|c|c|c|c|c|c|c|}
\hline & & 性別 & & 歯 & 者 & & 生 & 者 & & 生 歯 & 一 未生 & 慜者 \\
\hline & & 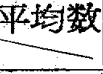 & $\mathrm{N}_{\mathbf{1}}$ & $\overline{\mathbf{X}}$ & $S^{2} x$ & $\mathrm{~N}_{2}$ & $\overline{\mathbf{Y}}$ & $\mathbf{S}^{2} \mathbf{Y}$ & n & d & $\omega^{2}$ & $t_{0}$ \\
\hline 50 & $\sim$ & 99 & & & & 12 & 27.17 & 14.7030 & : & & $m$ & mb:tan \\
\hline 100 & $\sim$ & 149 & 1 & 26.00 & 0 & 36 & 25.18 & 9.9811 & 35 & 0.72 & 9.9811 & 0.223 \\
\hline 150 & $\sim$ & 199 & 11 & 26.09 & 16.4891 & 45 & 27.20 & 12.1782 & 54 & -1.11 & 12.9276 & -0.916 \\
\hline 200 & $\sim$ & 249 & 38 & 26.21 & 5.7925 & 52 & 27.54 & 15.7419 & 88 & -1.33 & 11.5586 & -1.835 \\
\hline 250 & $\sim$ & 299 & 58 & 26.53 & 6.4503 & 21 & 26.90 & 8.1995 & 77 & -0.37 & 6.9046 & -0.553 \\
\hline 300 & $\sim$ & 349 & 48 & 25.73 & 8.4770 & 1 & 29.00 & 0 & 47 & -3.27 & 8.4770 & -1.112 \\
\hline 350 & $\sim$ & 399 & 18 & 27.06 & 5.9374 & 1 & 31.00 & 0 & 17 & -3.94 & 5.9374 & -1.786 \\
\hline 400 & $\sim$ & 449 & 3 & 25.33 & 4.3267 & & & & & & & \\
\hline & 計 & & 177 & 26.24 & 7.3341 & 168 & 26.85 & 12.8791 & 343 & -0.61 & 10.0339 & -1.786 \\
\hline & $\mathbf{K}=$ & & & & 10 & & & & & & & \\
\hline
\end{tabular}


男は両者間の差は、はとんどなく、女は乳䨑未生歯 者が生雪者よりも多い。

\section{む す び}

乳菌の生歯と出生時体重、身長、体重、胸囲及び頭 囲の発育量、父母の体重、身長及び母の年令との関係 を研究し次のような結果を得た。

1. 乳霜の生霜率は、男子が生後日数150～199日に $21.5 \%$ 、女子は $19.3 \%$ で男女とも生後日数の增すにつ れて増し、400〜49日に100.0\%で男女間の乳霜生歯 率の差はほとんどない。

2. 生後日数と乳雪の生霜数生後日数 $150 \sim 199$ 日 に、男子は平均0.5本、女子は平均0.1本で、男女とも 生後日数の增すにつれて増し、400～499日に男子は平 均9.0本、女子は平均9.3本、で男子が女子よりも乳歯 生雪数は多い。

3. 乳雪生歯者が末生菌者よりも男女とも出生時体 重が大である。

4. 乳䨑の生雪者が未生画者よりも身長発育量が大 である。

5. 乳雨の生霜者が末生霜者よりも体重発育量が大 である。

6. 乳䨑の生霜者と末生霜者の胸囲発育量の差はほ とんどない。

7. 乳蒾の生宩者と未生雨者の頭团発育量の差は著 しくない。

8. 乳歯の生霜と両親の平均身長との間には著しい 関倸はない。

9. 乳菌の生雪と両親の平均体重との関係はほとん どない。

10. 乳畨の生雨と母の平均年令との関保はほとんど ない。

\section{引用交 献}

1. 荷宮文夫：南満洲に扣ける日本人新生児の歯牙 葫出期の統計的観察、医学々生物学、12巻、1 号、
43頁、昭23年、 7

2. 今井武士：乳歯の萠出期とその㮌序、歯科学報、 52巻、9号、昭 $27 、 9$

3. 丹羽輝男：昭和25年より同年28年の間にれける 乳雬の萠出状況 (2)、東京都衛生局学会誌、 14 号、50頁、昭和 $29 、 3$

4. 同：京橋地区乳蒾萠出状況について、ロ 腔衛生学会雑誌、3 巻、2 号、94頁、昭29、9

5. 関口秀樹他：乳前菊の出短相に関する研究、口 腔衛生学会雑誌、5 巻、1 号、38頁、昭30、9

6. 笹子信一他：乳菌萌出に就ての統計的観察 (1) 特に生下時体重との関係、䨑科月報、 30 巻、 4 号、 244頁、昭32、3

7. 同：乳霜萌出とKaupの指数との関係、 日本公衆衛生雑誌、5 巻、11号、267頁、昭33、 11

8. 丹羽輝男 : 乳雪発育の統計、（日歯大）総合研 究報告集録医学及び薬学編（33年）、441頁、昭 34、 2

9. 藤田良甫：乳雬萌出に関する統計学的研究（1） 乳歯萌出の時期並に順序の観察、第 8 回日本公采 衛生学会総会、34頁、昭28、9

10. 風間敏男他：東京都に扔ける9ケ月児の曾牙の 萌出について、口腔衛生学会雑誌、9 巻、4 号、 84頁、昭34、12

11. 佐藤貞勝：菌牙の萌出と気候との関係、口腔衛 生学会雑誌、10巻、3号、21頁、昭35、11

12. 丹羽輝男 他：乳雪の出生順 位 別観察につ心 て、口腔衛生学会雑誌、10巻、4 号、197頁、昭 35, 12

13. 森田什祐：乳曾の生橉期の研究、医学研究、30 巻、9号、73頁、昭35、9

14. 村下秀雄他：乳雪の身体発育と乳雪の関係につ いて、口腔衛生学会雑誌、13巻、3、4号、6 頁、 昭38、12 


\title{
THE RELATIONSHIP OF DECIDOUS TEETH ERUPTION WITH BODY WEIGHT AT BIRTH AND OTHER POST - NATAL DEVELOPMENT AS STUDIED IN YOUNGSTERS
}

\author{
Fumio Ninomiya \\ Takara Fukunari \\ Yasutaka Wada \\ Yasuhiro Suehara \\ Department of preventive Dentistry (Direct. Prof. \\ F. Ninomiya) , Kyushu DentaI CoIlege ,Japan
}

\begin{abstract}
Various factors possibly affecting the eruption patterns of the human deciduous teeth were investigated on a total of 855 subjects, 507 males and 348 females, residing in kitakyushu district and ranging in age from 50 to 450 days. The items studied included the body weight at birth, the respective increment of the body weight, body height, chest girth and head girth of the subjects with advancing age, with reference to such factors as the body weight and height of their mothers and maternal age at the delivery.
\end{abstract}

Results obtained are summarized as follows.

1. The percent eruption of deciduous teeth was $21.5 \%$ for the males at the age range from 150 to 199 days, and $19.3 \%$ for the females at the same age range. This increased with advancing age, reaching $100 \%$ at the age range from 400 to 449 , without showing any significant sex difference.

2. The average number of erupted deciduous teeth at the age of 150 to 199 days counted 0.5 in the male and 0.1 in the female, and at the age of 400 to 449 days this increased to 9.0 in the male and 9.3 in the female. The male member had more erupted deciduous teeth than the female.

3. The body weight at birth was greater in subjects having erupted deciduous teeth than in those having no erupted teeth with both sexes.

4. The increment in the body height was likewise greater in the former group of subjects than in the latter.

5. The increment of the body weight also showed a similar trend like above.

6. With regard to the increment of the chest girth, there was hardly found any difference between both groups of subjects.

7. The adove situation also held true with the increment of the head girth.

8. No significant correlation was found between patterns of the deciduous teeth eruption of all the subjects and the average values of the body weight and height of their parents.

9. There was hardly found any significant correlation between patterns of the deciduous teeth eruption of all the subjects and the average age of their mothers at the delivery. 